\title{
Konsistensi dan AKURASi Data Hasil PENGUKURAN PADA Pengujian Aerodinamika Model Pesawat Jenis Penumpang SIPIL (AIRLINER) DI WIND TUNNEL BBTA3-BPPT
}

\author{
CONSISTENCY AND ACCURACY OF DATA MEASUREMENT RESUlTS \\ in Aerodynamic Testing of Civil Passenger (AIrliner) \\ MODEL IN WIND TUNNEL BBTA3-BPPT
}

\author{
Novan Risnawan ${ }^{1}$, F. Andree Yohanes ${ }^{1}$, Sunarno ${ }^{1}$, Alief Sadlie K. ${ }^{1}$ \\ ${ }^{1}$ Balai Besar Teknologi Aerodinamika, Aeroelastika dan Aeroakustika - BPPT \\ Kawasan PUSPIPTEK Gedung 240, Setu, Tangerang Selatan - Banten, Indonesia
}

\begin{abstract}
Abstraks
Pengujian aerodinamik sebuah model pesawat di terowongan angin merupakan tahap penting dalam proses desain pesawat. Balai Besar Teknologi Aerodinamika, Aeroelastika dan Aeroakustika (BBTA3) telah melakukan pengujian sebuah model pesawat bertipe penumpang sipil (airliner) untuk mendapatkan data karakteristik aerodinamika di terowongan angin ILST. Data hasil pengujian ini akan digunakan di dalam proses disain untuk memprediksi kinerja dan kestabilan pesawat sehingga data tersebut harus konsisten dan akurat. Tulisan ini mendiskusikan proses pengecekan konsistensi dan akurasi data dengan melakukan pengujian keberulangan dekat dan pengujian keberulangan jauh sehingga hasil pengukuran dapat dinyatakan valid dan dapat digunakan untuk mewakili keabsahan seluruh data pengukuran.
\end{abstract}

Kata Kunci : Konsistensi data hasil pengujian, wind tunnel, aerodinamika.

\begin{abstract}
Aerodynamic testing of an aircraft model in wind tunnel is important step in an aircraft design process. National Laboratory of Aerodynamic, Aeroelastic and Aeroacoustics Technology (BBTA3) have conducted a testing of a type of civilian passenger aircraft model to obtain aerodynamic characteristics data in ILST wind tunnel. The test result will be used in design process to predict performance and stability, so that the data must be consistent and accurate. This paper discusses the process of data consistency and accuracy checking by performing short repeatability and long repeatability testing so that the measurement results can be regarded valid and can be used to represent the validity of whole measurement data.
\end{abstract}

Keywords: Consistency of test result data, wind tunnel, aerodynamics.

\section{Pendahuluan}

Evaluasi rancang bangun pesawat terbang pada tahapan desain maupun pengembangan dapat dilakukan berdasarkan hasil pengujian dari terowongan angin. Evaluasi ini bersifat prediksi prestasi terbang pesawat berdasarkan data karakteristik aerodinamik model. Karena bilangan Reynold terbang pesawat dapat dicapai dalam terowongan angin, maka karakteristik aliran di sekitar pesawat tidak berbeda jauh dengan model dan mengesampingkan pengaruh slipstream dari propulsi pesawat.

Pengujian Aerodinamik Model pesawat di wind Tunnel merupakan tahap penting dalam proses desain pesawat, BBTA3 sebagai Balai Besar Teknologi Aerodinamika Aeroelastika dan Aeroakustika telah melakukan pengujian model Pesawat dengan jenis Penumpang sipil (AirLiner) dengan tujuan mendapatkan data karakteristik aerodinamika. Dalam pembuatan

* Novan Risnawan. Tel: +62 217560902 suatu pesawat terbang, suatu analisis sebelum terbang

E-mail: novan.risnawan@bppt.go.id terhadap kinerja aerodinamika dari pesawat tersebut 
sangat diperlukan, terutama untuk daerah dimana metoda analitik/empirik tidak dapat menjangkaunya seperti perkiraan CLmax, karakteristik stall, fungsi-fungsi high lift device dan lain-lainnya.

Dari beberapa metoda analisis aerodinamika, metoda pengujian wind tunnel terhadap model pesawat masih diyakini sebagai metoda yang cukup efektif untuk memprediksikan beban aerodinamika dan stabilitas pesawat yang ingin dibuat. Model pesawat yang akan di uji di wind tunnel harus disesuaikan dengan fasilitas uji terutama similaristas bentuk dan ukuran model penuh yang memenuhi kriteria pengujian wind tunnel. Model uji pesawat jenis penumpang (AirLiner) mempunyai skala 1:9 dan diuji pada kecepatan $70 \mathrm{~m} / \mathrm{s}$.

\section{Pengujian Model Pesawat Jenis Penumpang di Dalam Terowongan ANGIN ILST}

Pengujian ini dilaksanakan menggunakan terowongan angin ILST (Indonesian LowSpeed Tunnel). ILST merupakan "terowongan angin sirkuit tertutup" yang memiliki seksi uji dengan penampang $3 \mathrm{~m}$ x 4 $\mathrm{m}$, dengan panjang $10 \mathrm{~m}$, bertekanan atmosfir (atmosphere pressurized) dan kecepatan angin maksimum $80 \mathrm{~m} / \mathrm{s}$ dengan Mach Number 0.2. Seksi uji dari terowongan angin ini dilengkapi dengan dua buah turn table atas dan bawah dengan diameter $3 \mathrm{~m}$ yang bergerak secara sinkron. Turn table ini dapat diputar hingga \pm 90 derajat. Terowongan angin dilengkapi dengan honeycomb dan tiga lapis fine turbulence screen. Variasi kecepatan angin di dalam seksi uji kurang dari $0.2 \%$ dari harga rata-rata. Variasi tekanan static dalam arah aliran dalam rentang $\pm 0.3 \%$ dari tekanan dinamik pada kecepatan $70 \mathrm{~m} / \mathrm{s}$. Flow angularity \pm 0.1 derajat untuk pitch dan \pm 0.2 derajat untuk sudut yaw.

Penampang akhir seksi uji sedikit lebih besar, inklinasi terhadap sumbu penampang sekitar 2 derajat untuk menjaga deviasi bouyancy di dalam seksi uji sekecil mungkin. Lapisan batas di sekitar dinding seksi uji memiliki ketebalan sekitar $11 \mathrm{~cm}$ pada sisi kiri dan kanan, dan $13 \mathrm{~cm}$ pada bagian lantai dan langitlangit. Dengan demikian blockage area dari seksi uji adalah 90\% dari luas penampang seksi uji.

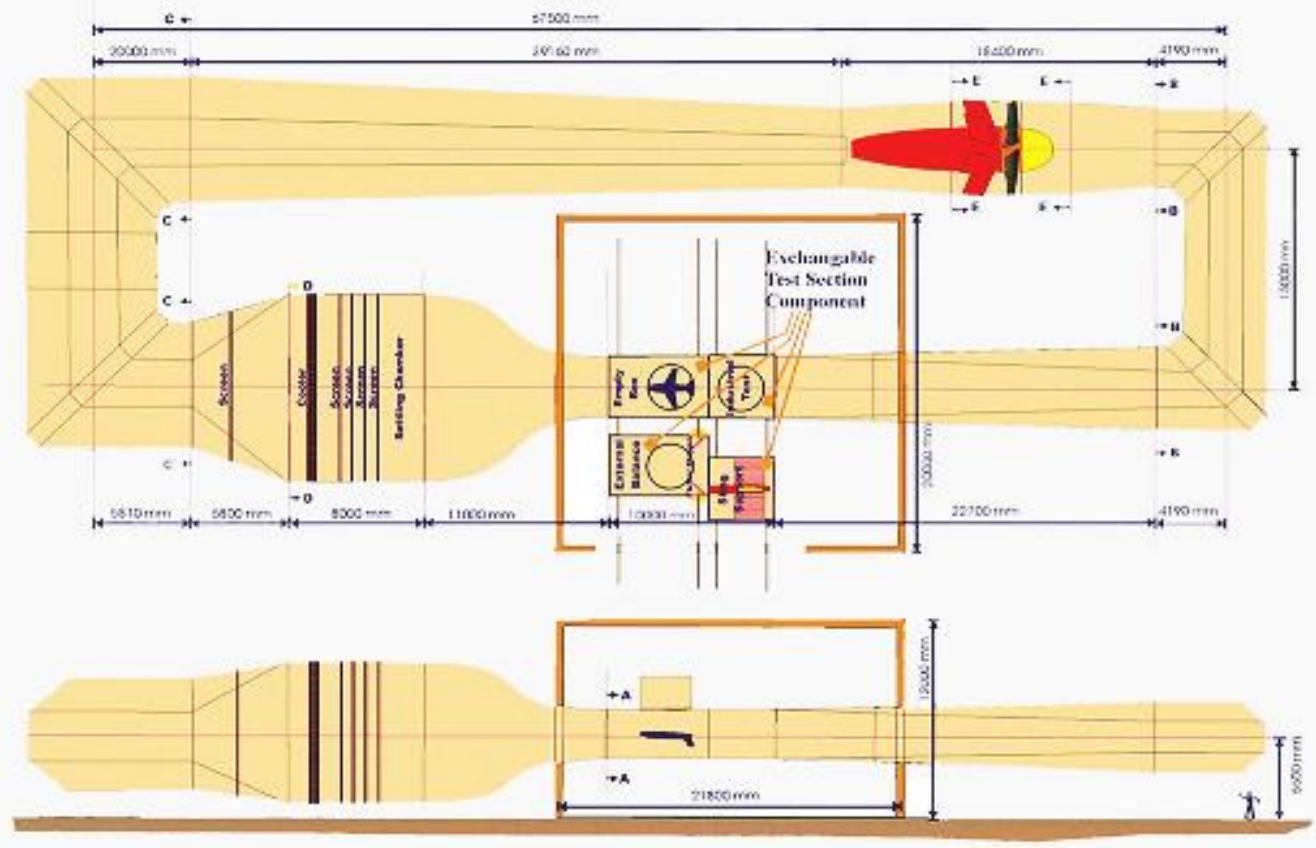

Gambar.2.1. terowongan angin jenis tertutup ILST-BBTA3

External balance men-support model uji dan terletak di atas seksi uji, mempunyai platform bertipe $T$ shaped, yang dihubungkan ke "earth-frame" melalui 6 loadcell (Q1 s/d Q6). "Earth-frame" , platform dan model dapat digerakkan memutar pada sumbu vertikal, begitu juga turn table atas dan bawah. Keenam loadcell tersebut dihubungkan ke LLI (Low Level Interface) untuk mengukur gaya. Hasil pengukuran gaya oleh loadcell dapat diturunkan dan diperoleh perhitungan gaya dan momen aerodinamis yang terjadi pada balance center. Extermal balance ILST yang dipergunakan mempunyai kapasitas seperti berikut :

Tabel.1.1. Nama komponen dan konfigurasi model. 


\begin{tabular}{crlrcr}
\hline & & & & & \\
No. & & Components & $\begin{array}{c}\text { Max Loads } \\
{[\mathrm{N}] \text { or }[\mathrm{Nm}]}\end{array}$ & \multicolumn{2}{c}{ Absolute Accuracy } \\
\cline { 5 - 6 } & & & 17500 & 0.02 & 3.5 \\
\hline 1 & K1 & Lift & 3500 & 0.02 & 0.7 \\
2 & K2 & Drag & 3750 & 0.03 & 1.125 \\
3 & K3 & Pitching Moment & 3500 & 0.02 & 0.7 \\
4 & K4 & Side Force & 3250 & 0.02 & 0.65 \\
5 & K5 & Yawing Moment & 3000 & 0.04 & 1.2 \\
\hline 6 & K6 & Rolling Moment & &
\end{tabular}

\section{A. Konfigurasi dan Pengaturan Model Dalam Seksi Uji}

Model yang dipakai adalah Model Pesawat Jenis Penumpang Sipil pada Exp-224 skala 1 : 9. Posisi model untuk pengujian ini adalah upside down. Di dalam model bagian depan dipasang sensor pengukur sudut $Q$-Flex yang terhubung keluar dengan kabel berpelindung. Model tergantung di wing strut pada bagian sayap (wing) dengan menggunakan pitching wire dan preload wire pada posisi hidung dari model serta dibebani preload sebesar $180 \mathrm{~kg}$. Setelah model terpasang di wingstrut dilakukan alignment dengan menggunakan alat ukur sudut inclinometer yg diletakkan di center fuselage.
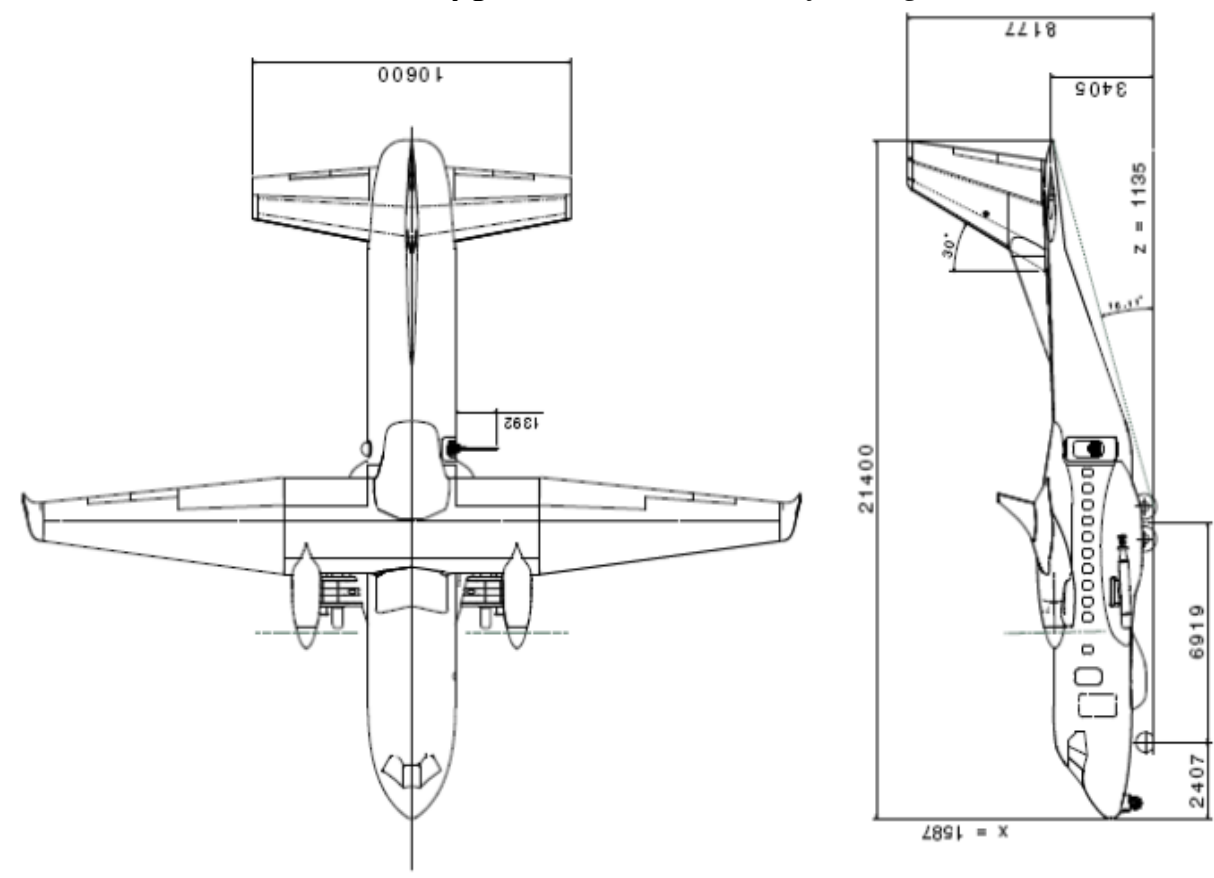

Gambar.2.2. Full Model Pesawat

Jarak antara wing struts disesuaikan dengan posisi adaptor di sayap model. Untuk mengurangi pengaruh interferensi adaptor dengan permukaan sayap saat pengukuran gaya dan momen, maka model dipasang pada posisi upside down. Wing struts dibungkus dengan wind fairing untuk mengurangi pengaruh ulakan pada model. Wind fairing dipasang sedemikian pada meja putar sehingga posisi wind fairing terhadap arah angin datang selalu paralel.

Pada model dipasang pitching wire yang menghubungkan antara model dengan turn buckle yang memungkinkan model untuk melakukan gerak pitch. Sementara di bagian bawah model di pasang beban preload yang disangkutkan ke model dengan bantuan preload wire. Besarnya beban yang dipasang disesuaikan dengan prediksi momen pitching maksimum yang akan dialami model. 
Setelah model terpasang, maka dilakukan pengukuran posisi model di dalam seksi uji. Pengukuran ini dilakukan untuk memastikan bahwa posisi awal model di dalam seksi uji tepat di tengah-tengah seksi uji, sudut model terhadap 3 sumbu putarnya masing-masing adalah nol. Untuk kebutuhan ini digunakan alat bantu inclinometer dan theodolite. Di dalam seksi uji terdapat tanda garis yang digunakan sebagai referensi arah dan sudut. Sementara referensi pada model biasanya menggunakan rangka model yang paralel dengan sumbu longitudinal model.

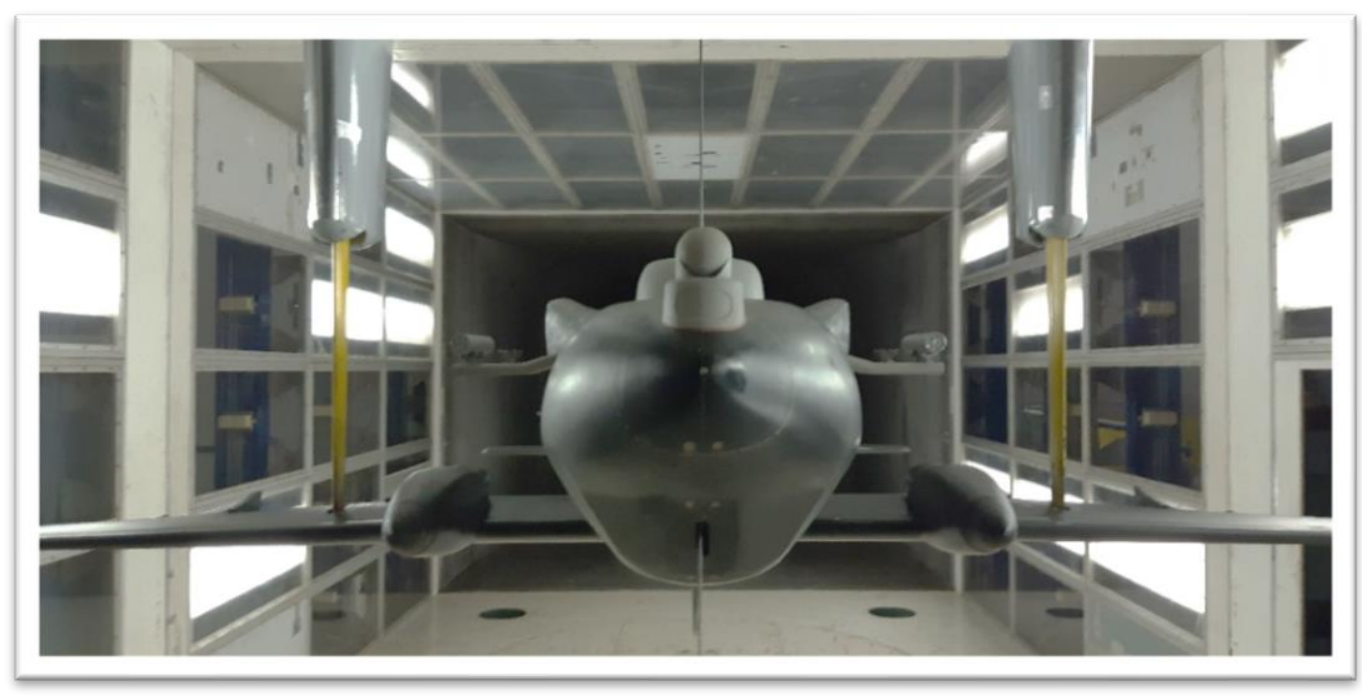

Gambar.2.3. Model Pesawat di Seksi Uji

Sudut yaw model adalah sudut yang dibentuk oleh sumbu seksi uji dan sumbu longitudinal model dengan aerodynamic center sebagai titik putar pada bidang XY model pesawat. Gerakan yaw model dihasilkan oleh gerak meja putar di langit-langit seksi uji dan besar putarannya diukur oleh encoder di dalam timbangan luar. Data yang direkam encoder dikirim ke data akuisisi dalam satuan derajat sudut.

Keterangan mengenai komponen dan Konfigurasi model pada pengujian dapat dijelaskan sebagai berikut:

Tabel.2.2. Nama komponen dan konfigurasi model.

\begin{tabular}{ll}
\hline \multicolumn{1}{c}{ Kode } & \multicolumn{1}{c}{ Komponen } \\
\hline \hline W3 & Wing (sayap) \\
\hline B & Body (badan) \\
\hline $\mathbf{N}$ & Nacelle \\
\hline $\mathbf{G}$ & Landing Gear Fairing \\
\hline $\mathbf{H}$ & Vertical Tail ( Ekor Vertikal) \\
\hline F & Horisontal Tail ( Ekor Horisontal) \\
\hline O & Flir \\
\hline R & Buble Windows \\
\hline Ya & Belly Radome \\
\hline Ya1 dan Ya2 & Posisi Pylon $0^{\circ}$ di tengah leanding fairing \\
\hline Yb dan Yc & Posisi Pylon -1.5 $5^{\circ}$ dan $-3^{\circ}$ di tengah leanding fairing \\
\hline L1 dan L2 & Posisi Pylon di depan dan belakang leanding fairing \\
\hline L3 dan L4 & Posisi Launcher di kanan model \\
\hline K & Posisi Launcher di kiri model \\
\hline T1 dan T2 & Canon \\
\hline T3 dan T4 & Posisi Torpedo di kanan model \\
\hline W3BNGVH & Posisi Torpedo di kiri model \\
\hline W3BNGVHFRO & Konfigurasi \\
\hline
\end{tabular}




\section{W3BNGVHFROYaK WBNGVHFROYa(L1,T2) - $(\mathrm{T} 3, \mathbf{L} 4) \mathrm{K}$ \\ Basic configuration, Pylon tengah, Canon kiri configuration Basic configuration, Pylon tengah (Launcher, Torpedo) kanan - (Torpedo, launcher) Canon kiri configuration}

\section{B. Akuisisi Data dan Data Processing}

Di dalam perangkat lunak juga dilakukan proses komputasi yang berkenaan dengan koreksi instrumentasi, koreksi aliran terhadap kondisi seksi uji saat kosong dan koreksi dari model. Koreksi instrumentasi diperoleh dari data kalibrasi alat ukur dan kondisi lingkungan yang mempengaruhi instrumen saat akan melakukan pengukuran. Koreksi aliran seksi uji saat kosong diperoleh dari hasil kalibrasi seksi uji saat kosong tanpa model. Sementara koreksi terhadap model disesuaikan dengan geometri model.

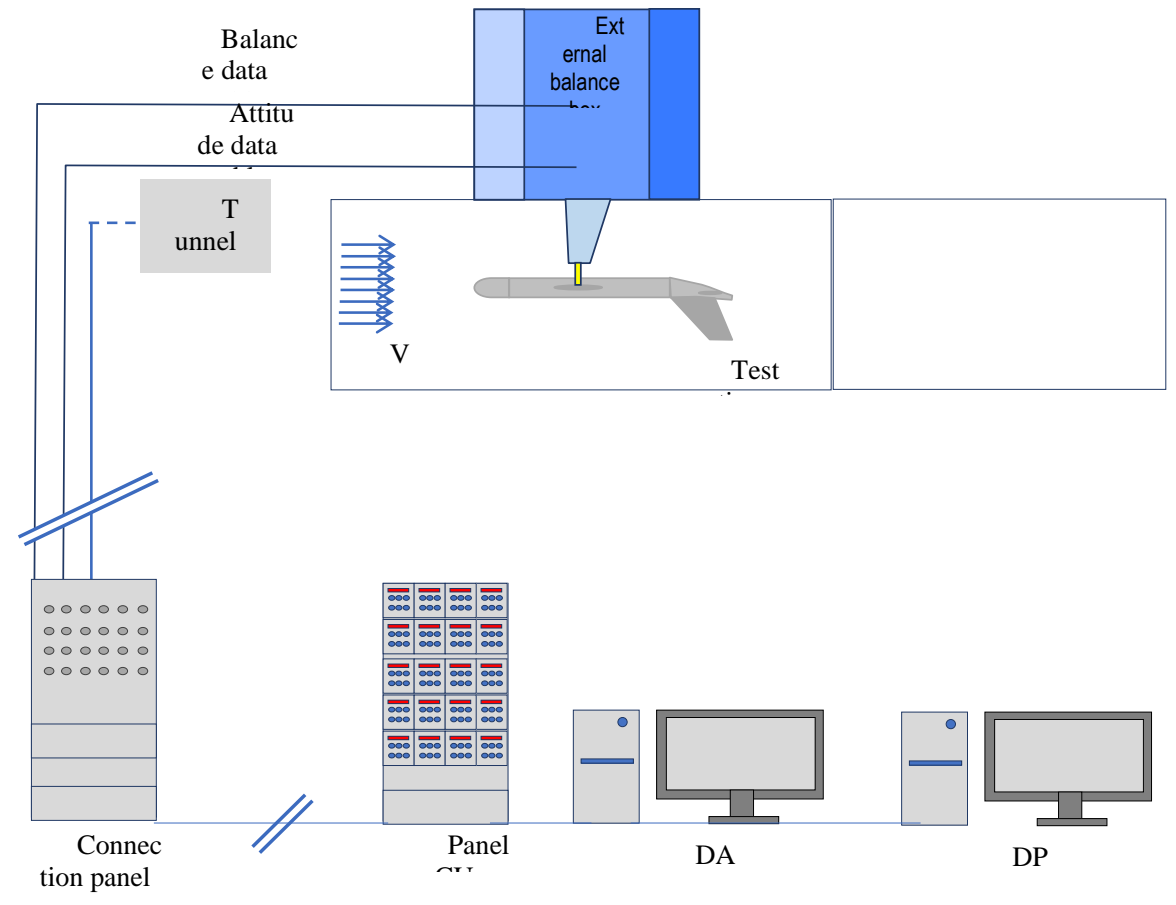

\section{Gambar .2.4. Setup Akuisisi Data dan Data Processing}

Pengolahan data selama pengujian dilakukan dengan memasukkan beberapa koreksi, yaitu weight correction, zero correction, tunnel wall interference correction dan solid-blockage correction. Koreksi tareforce dilakukan secara offline diakhir pengujian. Koreksi data yang dilakukan meliputi hal-hal berikut :

\section{a. Zero Correction}

Koreksi ini hanya dilakukan pada proses off-line saja, yaitu pemrosesan data setelah pengujian selesai dilakukan. Ada pembacaan zero pertama dan zero kedua disetiap pengujian, dimana pembacaan data pengujian terletak diantaranya. Pengukuran zero dilakukan untuk mendapatkan pembacaan tiap instrument sebelum dan sesudah pengujian dengan kondisi tanpa angin.

\section{b. Weight Correction}

Selama pengujian, model digerakkan dengan beberapa posisi sudut serang. setiap posisi sudut serang ini akan merubah lokasi titik berat dari model beban preload dan pusat titik berat $\alpha$-segment dari external balance terhadap pusat balance. Hal ini akan merubah hasil pengukuran pitching moment, yang bukan disebabkan oleh gaya aerodinamis. Koreksi ini dilakukan dengan pengujian tanpa angin, sebelum pengujian dengan angin dilakukan. Data yang didapatkan dari setiap perubahan sudut serang ini kemudian akan dipakai untuk mengkoreksi data dari hasil pengujian pada sudut serang yang sama. Setiap perubahan yang berpengaruh pada berat model, terutama yang mempengaruhi pusat berat model.

\section{c. Aerodynamic Tare Force Correction pada Wing Strut}

Data hasil pengujian dikoreksi terhadap gaya-gaya aerodinamik yang terjadi akibat sebagian strut terkena aliran udara (gaya-gaya tare). 
Pengukuran dilakukan tanpa model di dalam seksi uji, kecepatan angin $70 \mathrm{~m} /$ detik pada beberapa posisi sudut yaw ( $\beta$ ), mencakup semua nilai $\beta$ pada pengujian ini.

\section{d. Tunnel Wall Interference Correction}

Koreksi aliran yang mendekati sayap

$$
\Delta \alpha=C_{1} C_{L w}^{\prime}
$$

Dimana $C^{\prime}{ }_{L w}$ adalah koefisien lift tidak terkoreksi dalam wind axes.

$$
C_{1}=\left(\delta_{1}+\frac{c \delta_{1}}{2 \beta_{1} h}\right) \frac{S}{C} \frac{180}{\pi}
$$

Koreksi aliran yang mendekati ekor horisontal (horizontal tail) :

$$
\Delta \alpha_{h}=C_{8} C_{L w}^{\prime} \quad \text { eq. } 2.3
$$

Koreksi lift:

$$
\begin{array}{cc}
C_{L}=C_{L w}^{\prime} \operatorname{Cos}(\Delta \alpha)-C_{D w}^{\prime} \operatorname{Sin}(\Delta \alpha)+\Delta C_{L} & \text { eq. } 2.4 \\
\Delta C_{L}=-C_{9}\left(\Delta \alpha_{h}-\Delta \alpha\right) & \text { eq. } 2.5
\end{array}
$$

Di mana $C^{\prime}{ }_{D w}$ adalah koefisien drag tidak terkoreksi di dalam wind axes dan $\Delta C_{L}$ merupakan koreksi koefisien lift yang disebabkan aliran datang pada horizontal tail. C9 adalah factor koreksi koefisien lift.

Koreksi drag :

Koreksi yawing moment:

$$
C_{L}=C_{L w}^{\prime} \operatorname{Sin}(\Delta \alpha)+C_{D w}^{\prime} \operatorname{Cos}(\Delta \alpha) \quad \text { eq. } 2.6
$$

$$
C_{n w}=C_{n w}^{\prime} \operatorname{Cos}(\Delta \alpha)-C_{r w}^{\prime} \operatorname{Sin}(\Delta \alpha) \quad \text { eq. } 2.7
$$

Di mana $C^{\prime}{ }_{n w}$ dan $C^{\prime}{ }_{r w}$ adalah koefisien yawing moment dan rolling moment tidak terkoreksi dalam wind axis.

Koreksi rolling moment:

$$
C_{r w}=C_{n w}^{\prime} \operatorname{Sin}(\Delta \alpha)+C_{r w}^{\prime} \operatorname{Cos}(\Delta \alpha) \quad \text { eq. } 2.8
$$

Koreksi pitching moment pertama :

$$
\Delta C_{m 1}=C_{7} C_{L w}^{\prime}
$$

Dimana $\mathrm{C} 7$ adalah factor koreksi pitching moment pertama.

$$
C_{7}=\frac{\bar{c} \delta_{1}}{16 \beta_{1} h}\left[\left(\frac{c}{\bar{c}}\right)^{2}+\frac{1}{3}(A \tan (\Lambda))^{2}\left(2-\frac{c}{\bar{c}}\right)\right] \frac{\partial C_{L}}{\partial \alpha} \frac{S}{C} \quad \text { eq. } 2.10
$$

Koreksi pitching moment kedua :

$$
\Delta C_{m 2}=-C_{10}\left(\Delta \alpha_{h}-\Delta \alpha\right)
$$

Di mana C10 adalah factor koreksi pitching moment kedua. $C_{10}=\partial C_{m} / \partial \alpha_{h}$ adalah perubahan pitching moment akibat perubahan sudut serang horizontal tail.

\section{Metode dan Teknik Pengukuran}

Metoda pengukuran gaya dan momen aerodinamika model peasawat di wind Tunnel ILST menggunakan timbangan (External Balance). Skema lay-out External Balance di ILST Seperti terlihat pada Gambar 3.1, ada 6 buah load cell yang dapat mengukur gaya drag, lift, pitching momemt, side force, rolling moment, dan yawing momen secara bersamaan.

External Balance ILST terdiri dari suatu platform berbentuk-T yang terhubung dengan 6 load cells yang mengukur gaya dan momena erodinamika. Data dari load cell tersebut dihubungkan ke perangkat yang disebut Low Level Interface (LLI). Data yang diperoleh merupakan gaya dan momen dengan pusat di titik pusat balance. Selanjutnya, data tersebut dapat diproses untuk didefinisikan di titik yang diinginkan. Sedangkan skema/lay-out dari external balance diberikan dalam gambar 3.1. 


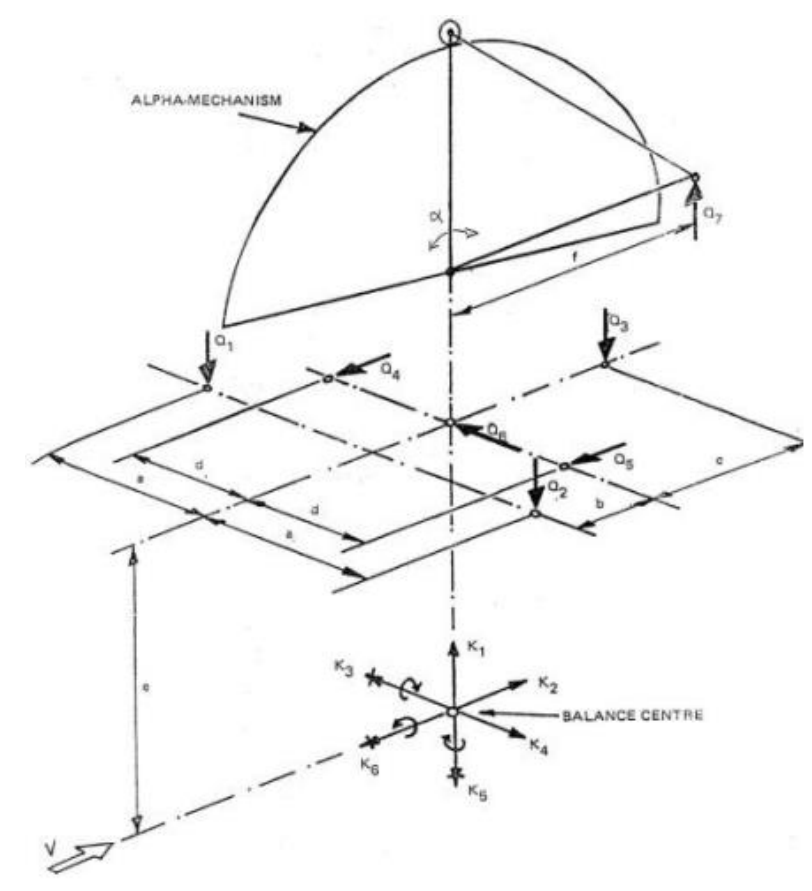

Gambar.3.1. Lay-Out External Balance dan Cells (Q1 s/d Q6)

\section{A. Konfigurasi Model Uji}

Proses pengukuran data dilukan untuk beberapa konfigurasi model pesawat diantaranya, Konfigurasi dasar (clean configuration) yaitu konfigurasi tanpa defleksi dari high lift devices yang dilakukan baik alpha polar maupun beta polar untuk memberikan gambaran umum dari karakteristik aerodinamika pesawat. Konfigurasi Stability Devices seperti defleksi elevator (dE), defleksi flap (dFlap) dan defleksi rudder (dRud) yang dilakukan baik dari alpha polar maupun beta polar untuk memperoleh informasi efektivitas dari bidang kontrol.

\section{HASIL DAN PEMBahaSAN}

Pengujian dimulai dengan konfigurasi clean W3BNGVH untuk mencari kesamaan baseline konfigurasi clean dengan pengujian sebelumnya. Di dalam test plan terdapat konfigurasi tail off W3BNG tetapi tidak diuji dan digantikan oleh konfigurasi lain yaitu konfigurasi pylon dengan sudut $-1.5^{\circ}$ dan $-3^{\circ}$.

Sebelum melakukan pembahasan lebih lanjut mengenai data karakteristik aerodinamika dari model uji, perlu dipastikan bahwa data yang diperoleh memiliki tingkat konsistensi yang cukup untuk dapat dinyatakan valid. Kondisi uji yang dipilih untuk mewakili keseluruhan data uji adalah; kondisi konfigurasi utuh tanpa defleksi bidang kendali pada variasi sudut.

\section{A. Pengulangan Konfigurasi Baseline Clean}

Konfigurasi baseline clean W3BNGVH dengan membandingkan hasil pengukuran yang sudah pernah di lakukan anatar Eksperimen 224 dan Eksperimen 162 diperlihatkan pada Gambar 4.1 sampai dengan Gambar 4.6. Perbedaan run pada Experimen 224 adalah penggunaan dua buah inclinometer yang berbeda. Run 09 lebih benar dibandingkan Run 08 karena menggunakan inclinometer yang sudah biasa dipakai. Sedangkan Run 08 menggunakan inclinometer yang baru dengan koefisien yang belum diinputkan dengan tepat. Run 08 dan Run 09 Experimen 224 berbeda jauh dibandingkan Run 71 Experimen 162. Perbedaan ini dapat berasal dari kualitas model uji yang sudah berubah menurun atau berasal dari pergeseran bacaan instrumentasi terowongan angin.

Kualitas model yang sudah berubah menurun tidak dapat dibuktikan kebenarannya karena tidak ada dokumen pemeriksaan koordinat permukaan (CMM). Begitu pula dengan kualitas terowongan angin yang sangat ditentukan oleh tunnel reference dan keakuratan external balance. Dari hasil kalibrasi empty test section terakhir di awal tahun 2018, koefisien external balance masih belum berubah sejak check load tahun 1997 dan komisioning tahun 1987. Dengan demikian fasilitas uji juga bukan merupakan penyebab dari perbedaan hasil ini. 
Solusi untuk permasalahan ini adalah mengambil data yang baru sebagai baseline yang baru sejauh pengujian keberulangan pendek (short repeatability) dan keberulangan panjang (long repeatability) menunjukkan hasil yang konsisten.

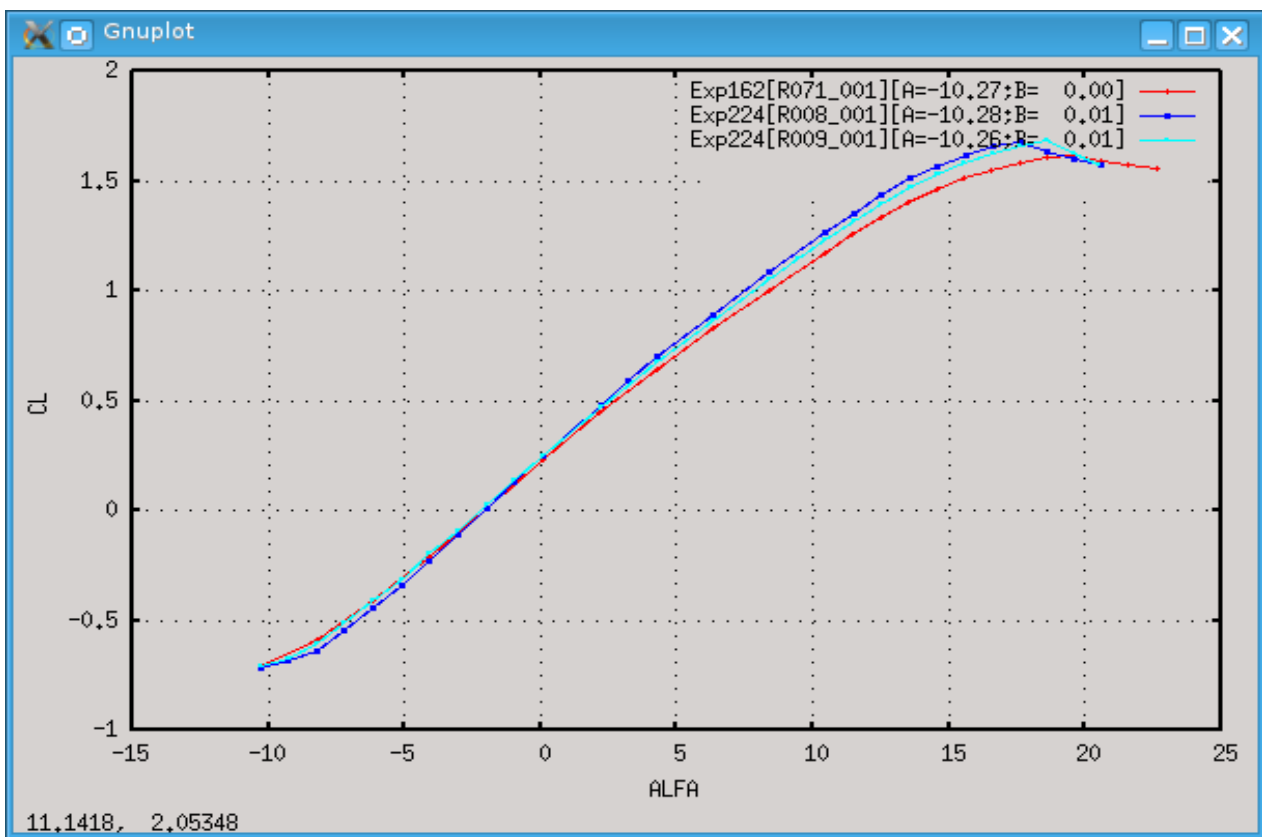

Gambar 4.1. Koefisien $C_{L}$ baseline clean.

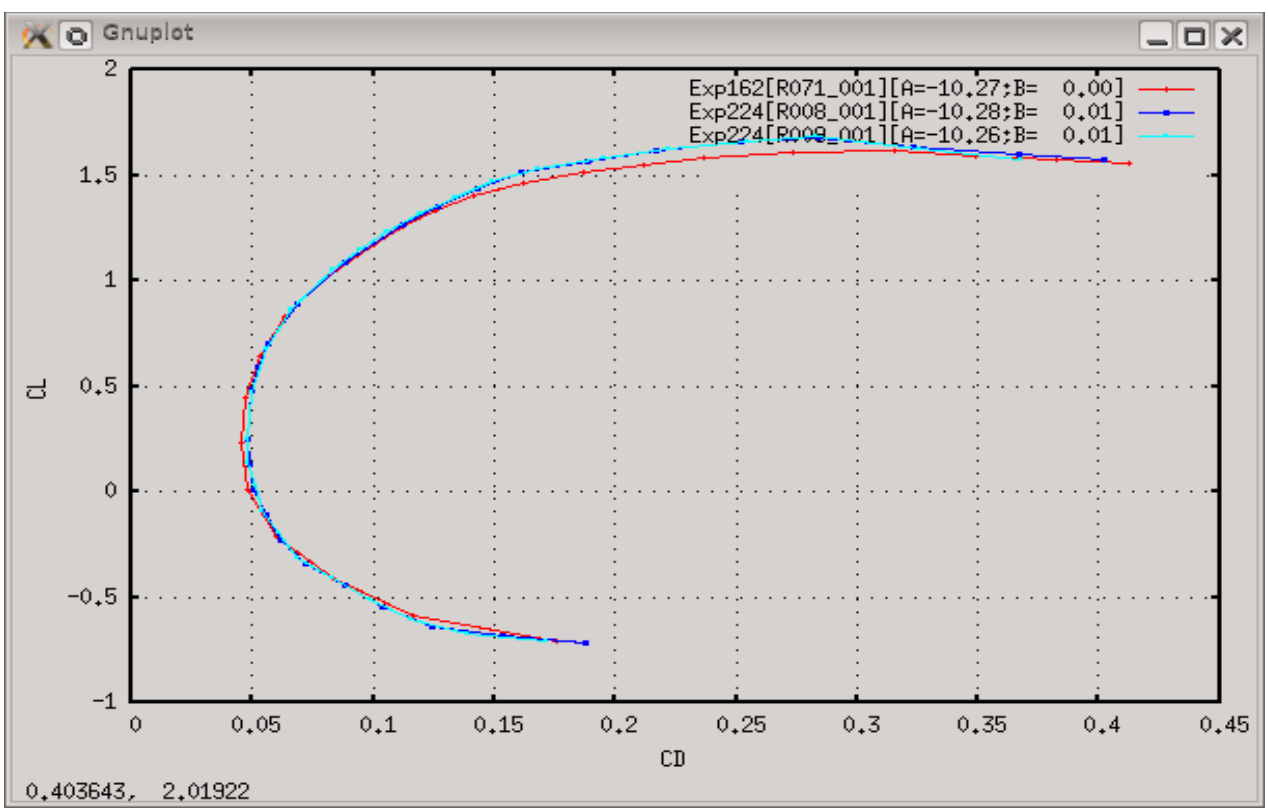

Gambar. 4.2. Koefisien $C_{D}$ baseline clean. 


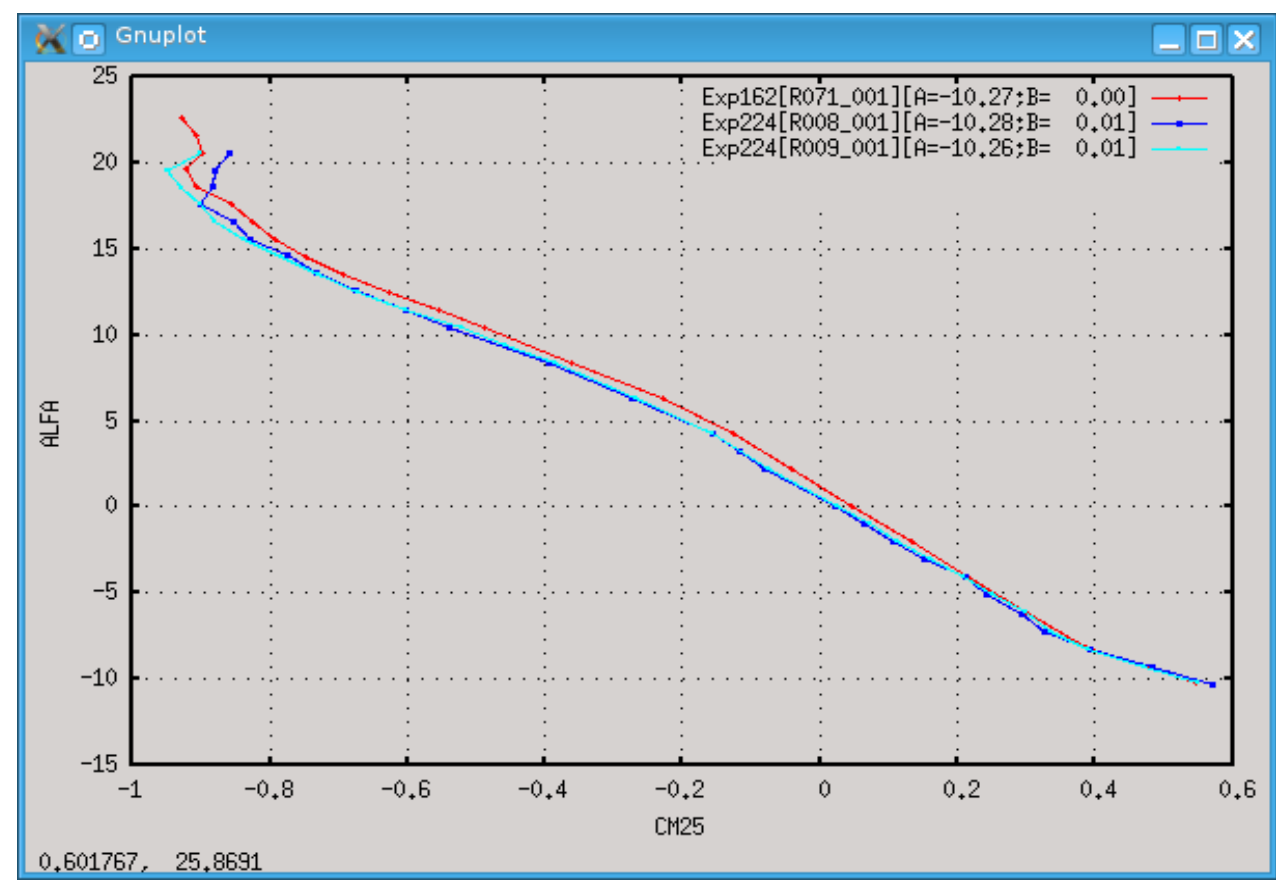

Gambar.4.3. Koefisien $C_{M .25}$ baseline clean.

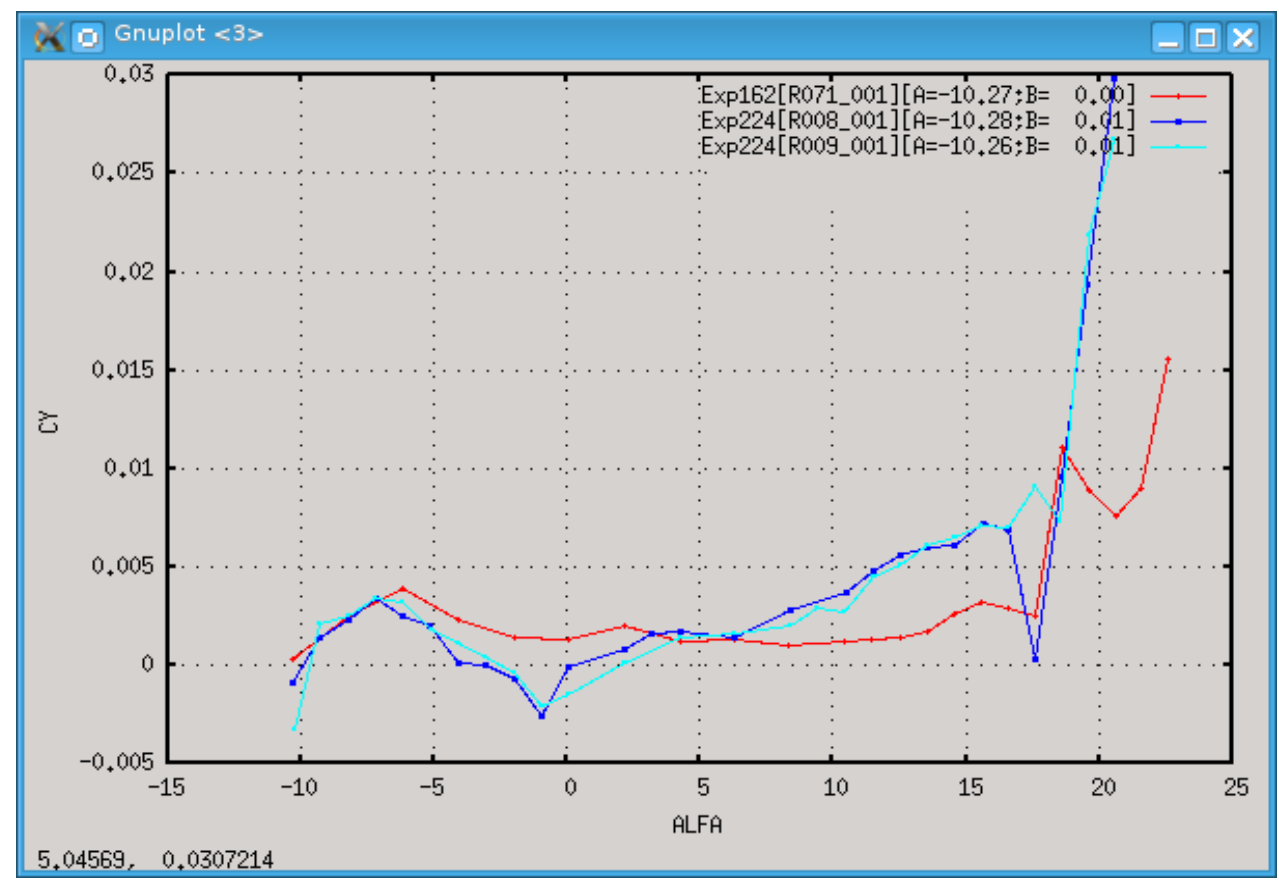

Gambar.4.4. Koefisien $C_{Y}$ baseline clean. 


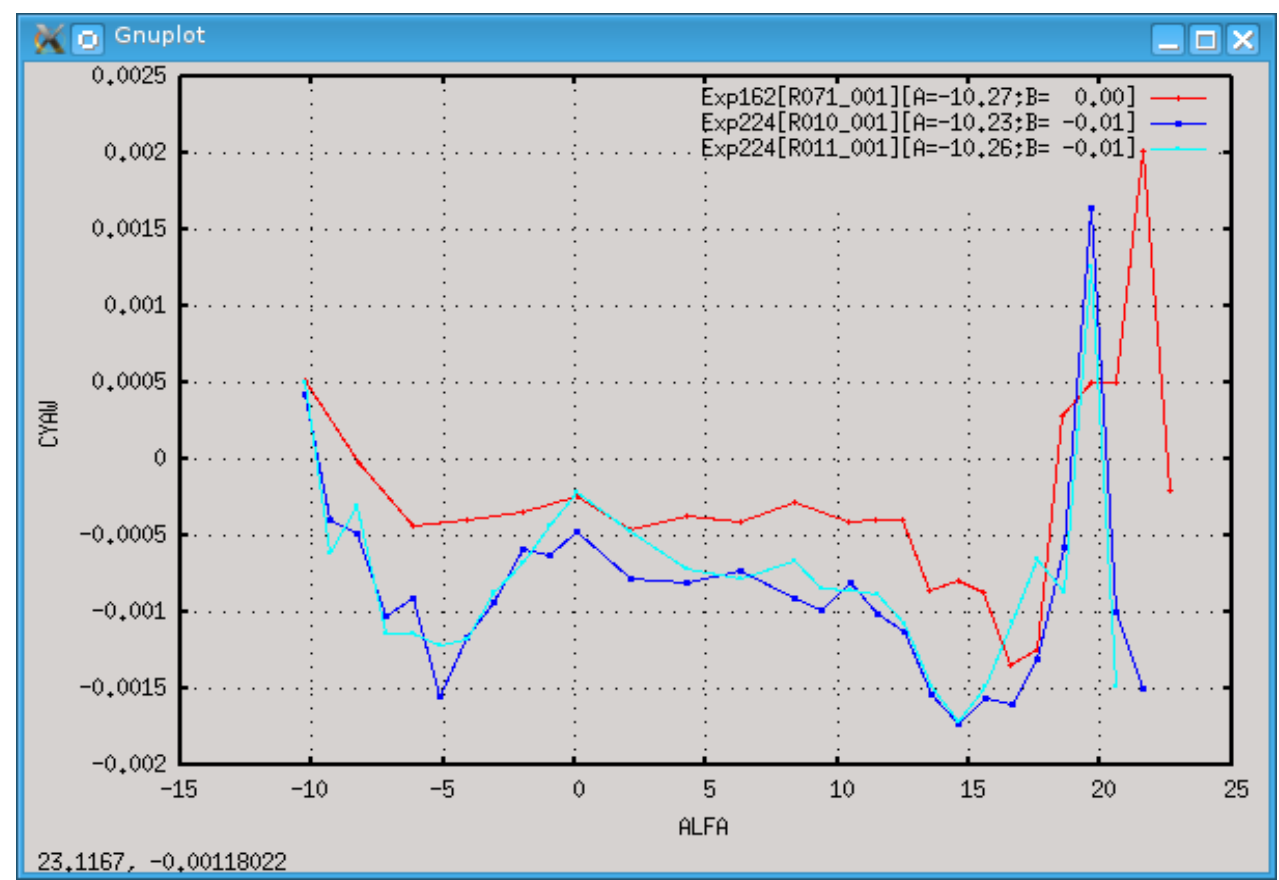

Gambar.4.5. Koefisien $C_{\text {Yaw }}$ baseline clean.

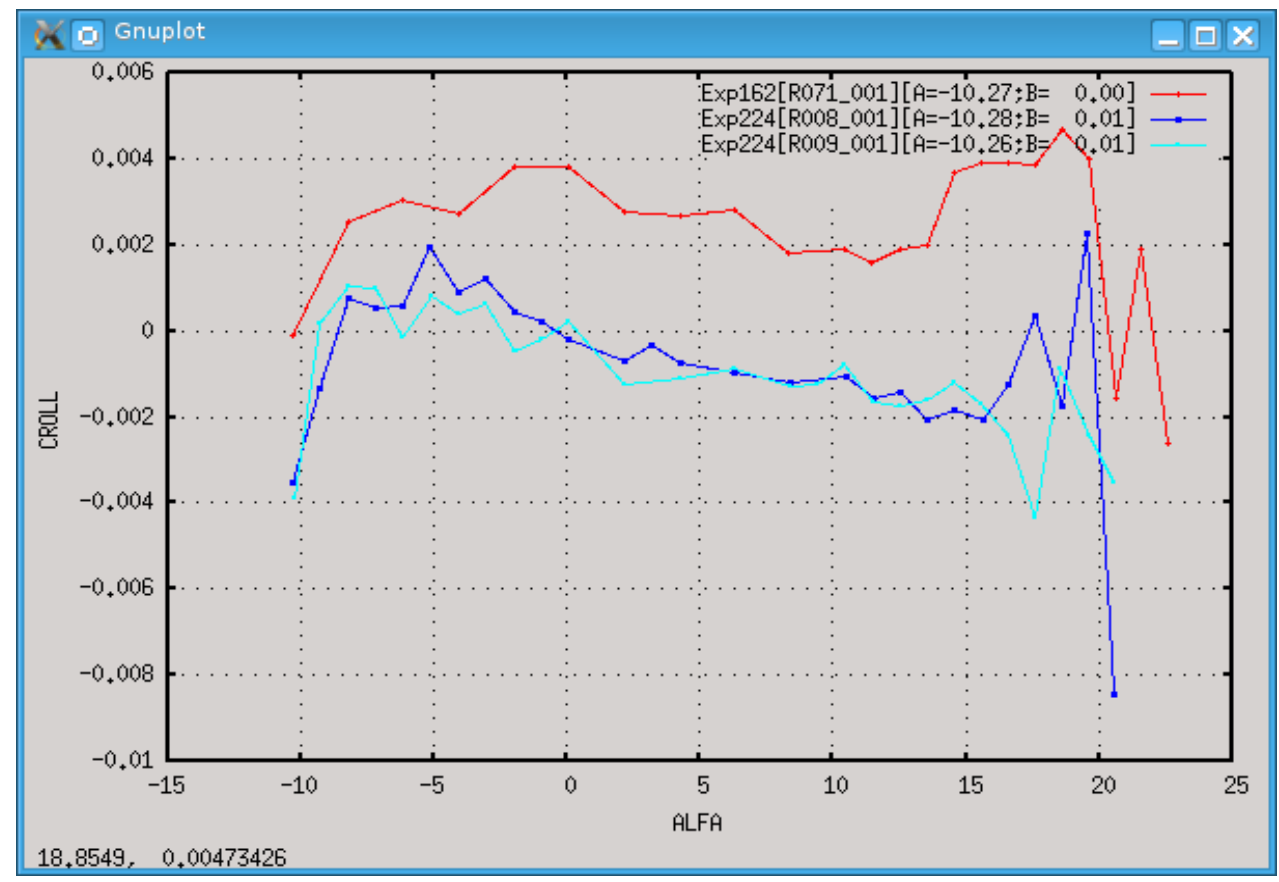

Gambar.4.6. Koefisien $C_{\text {Roll }}$ baseline clean.

\section{B. Konsistensi dan Akurasi}

Konsistensi di dalam tulisan ini dinyatakan dalam deviasi data. Selama pengujian konsistensi ditentukan dengan melakukan pengujian keberulangan dekat dan keberulangan panjang (short repeatability dan long repeatability). Hasil pengujian keberulangan dekat adalah Run 09, Run 10 dan Run 11 seperti ditunjukkan di dalam Gambar 4.7 sampai dengan Gambar 4.12. Kriteria keberulangan yang digunakan adalah harga deviasi rata-rata harus kurang dari lima kali resolusi bacaan external balance.

$$
\text { Average deviation } \leq(1 / f) E_{i} \quad \text { eq. } 4.1
$$

Dengan $E_{i}$ adalah akurasi (error) komponen external balance yang didefinisikan untuk ILST sebagai,

$$
E_{i}=\left[0.3+0.7 \frac{P_{i}}{P_{\max }}\right] 0.001 f P_{\max }
$$


Di mana $f$ adalah sensitivitas komponen external balance. Default harga $f$ adalah 1 , untuk ILST nilainya adalah 1/5. Sehingga untuk Dev $v_{\text {Avg }}$ persamaan (4.1) menjadi $5 E_{i}$. Tetapi kriteria ini masih terlalu ketat untuk pembebanan yang bresifat fluktuatif yang berasal dari ulakan gerakan udara. Dari pengamatan visual harian penyimpangan $1 \%$ dari nilai bacaan sudah dapat dikatakan dua data pengukuran berimpit. Pada laporan ini dipakai harga $0.5 \%$ dari harga bacaan atau sekitar $5 E_{i}$ dengan asumsi $f$ adalah 1.

Hasil dari perhitungan deviasi rata-rata seluruh range data baik linier dan nonlinier serta akurasi komponen external balance untuk pengujian keberulangan dekat ditunjukkan pada Tabel 4.1. Analisis keberulangan dan pengamatan visual data menunjukkan pengetesan berulang dengan sangat baik.

Tabel.2.1. Hasil tes keberulangan dekat.

\begin{tabular}{lllllll}
\hline & CL & CD & CM25 & CYAW & CROLL & CY \\
\hline \hline Deviasi rata-rata & 0.00392 & 0.00156 & 0.00642 & 0.00023 & 0.00075 & 0.00086 \\
Akurasi pengukuran & 0.01937 & 0.00390 & 0.00649 & 0.00086 & 0.00079 & 0.00218 \\
Kriteria & Repeat & Repeat & Repeat & Repeat & Repeat & Repeat \\
\hline
\end{tabular}

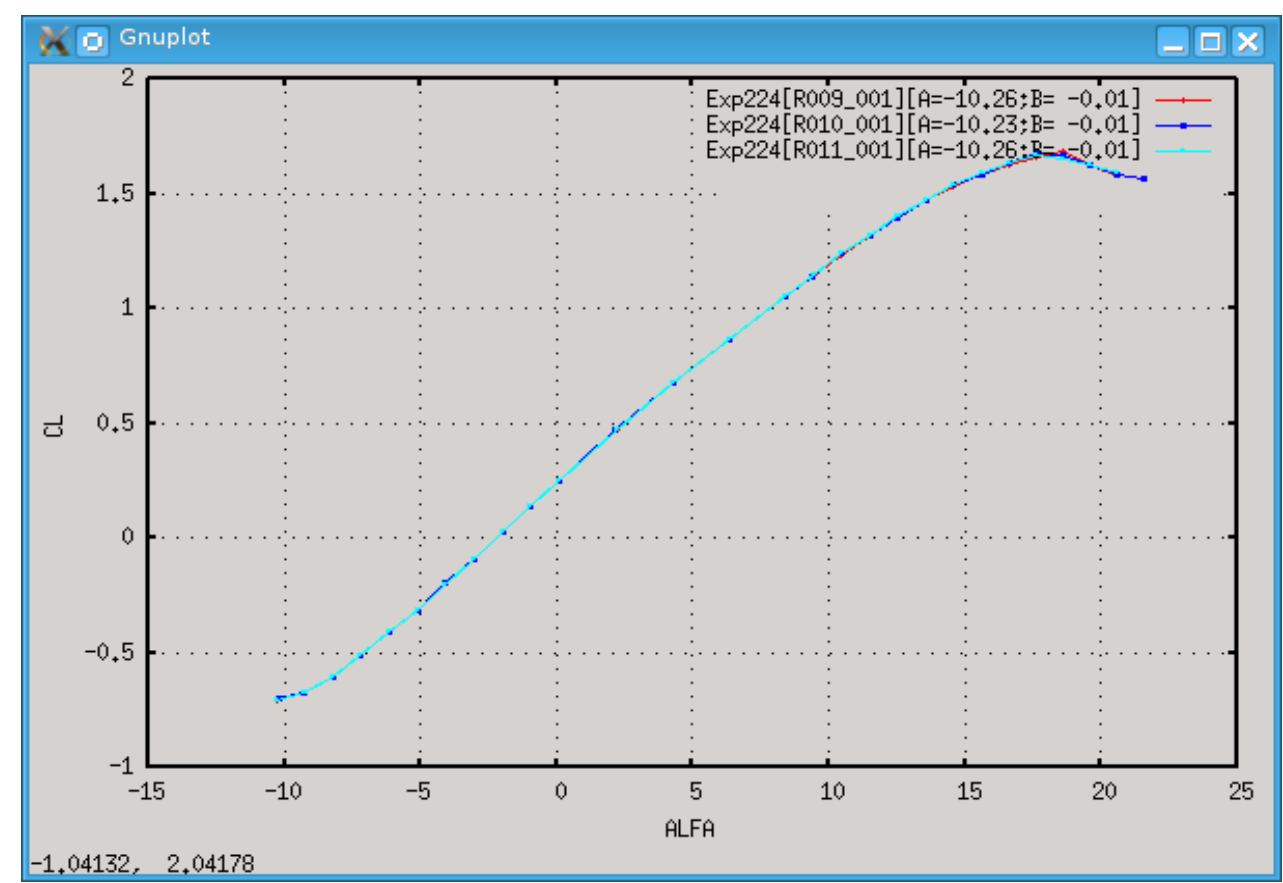

Gambar.4.7. Koefisien $C_{L}$ baseline clean. 


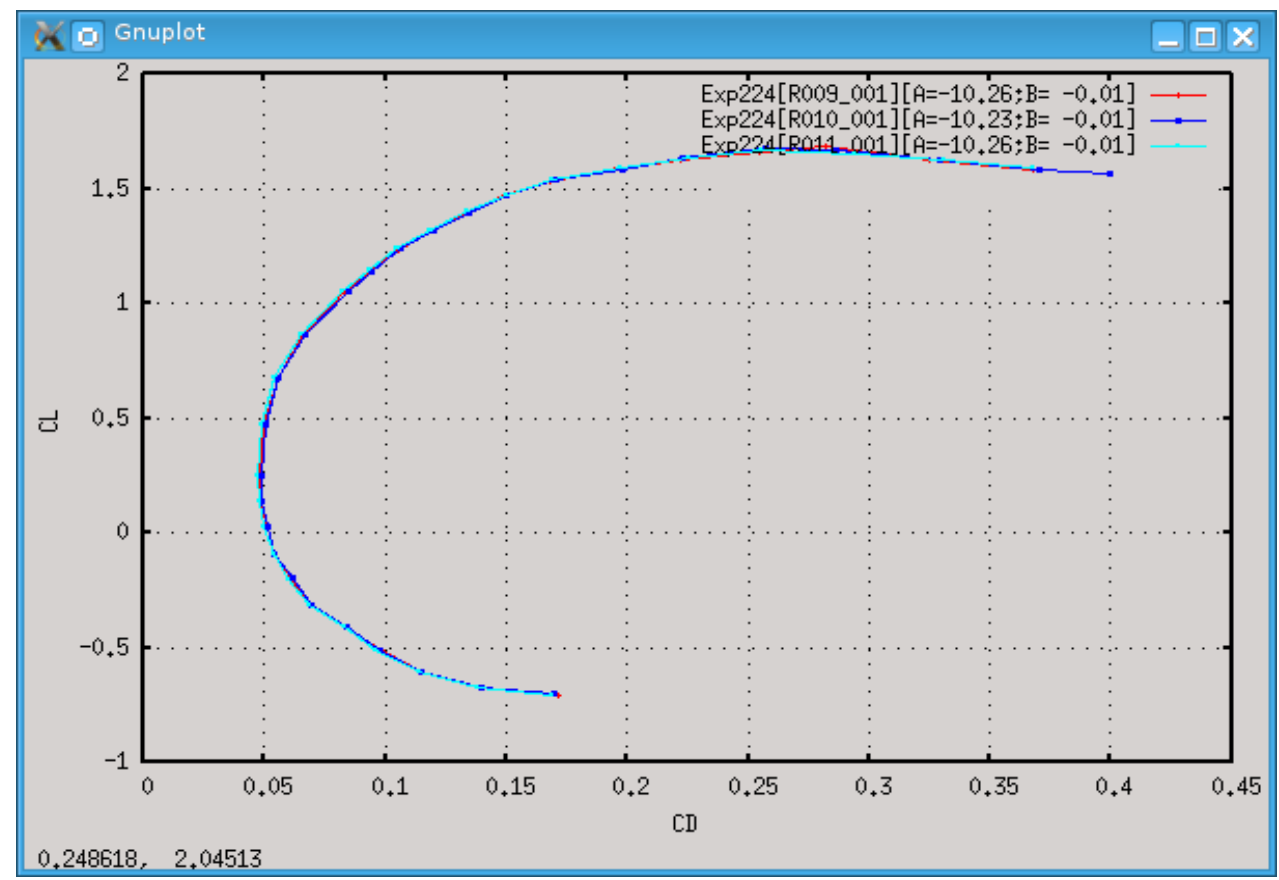

Gambar.4.8. Koefisien $C_{D}$ baseline clean.

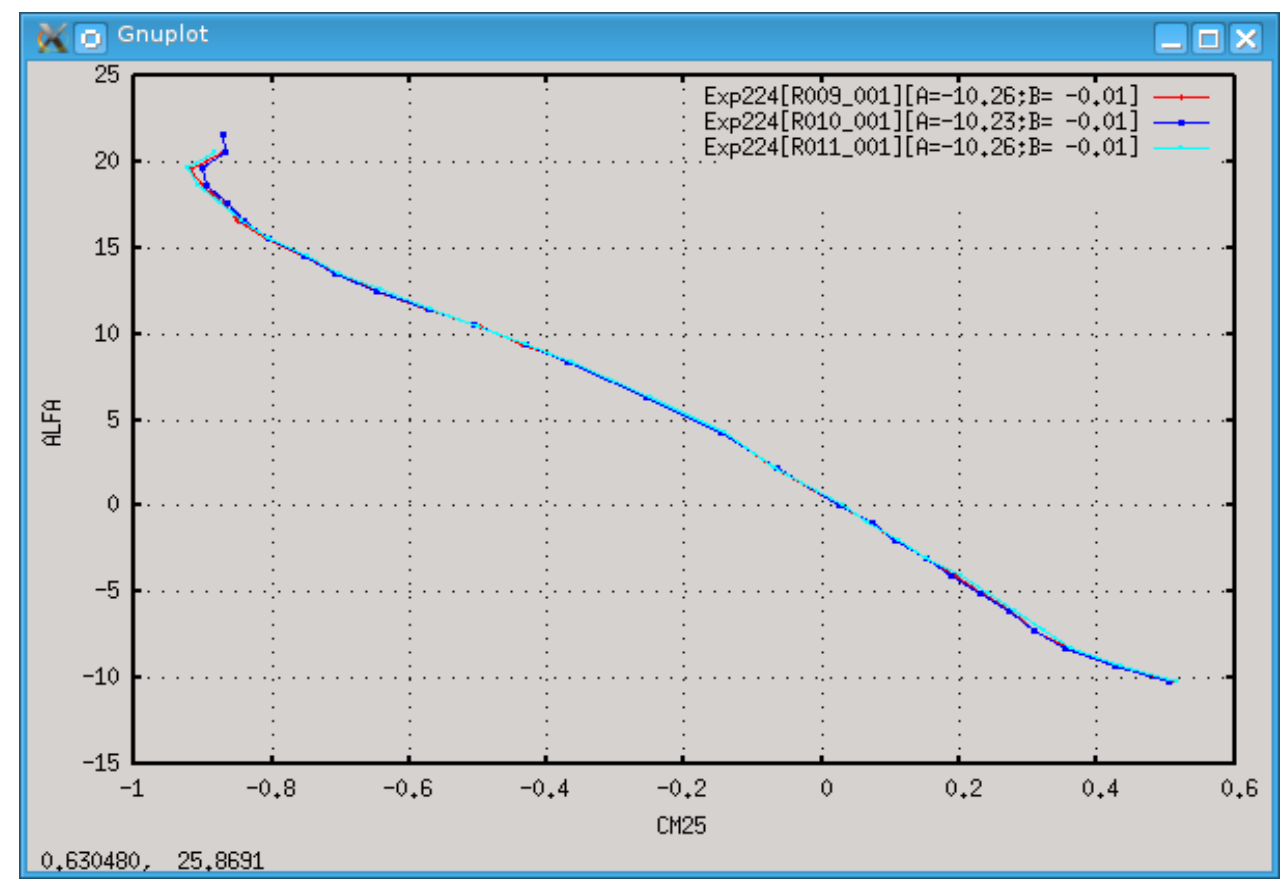

Gambar.4.9. Koefisien $C_{M .25}$ baseline clean. 


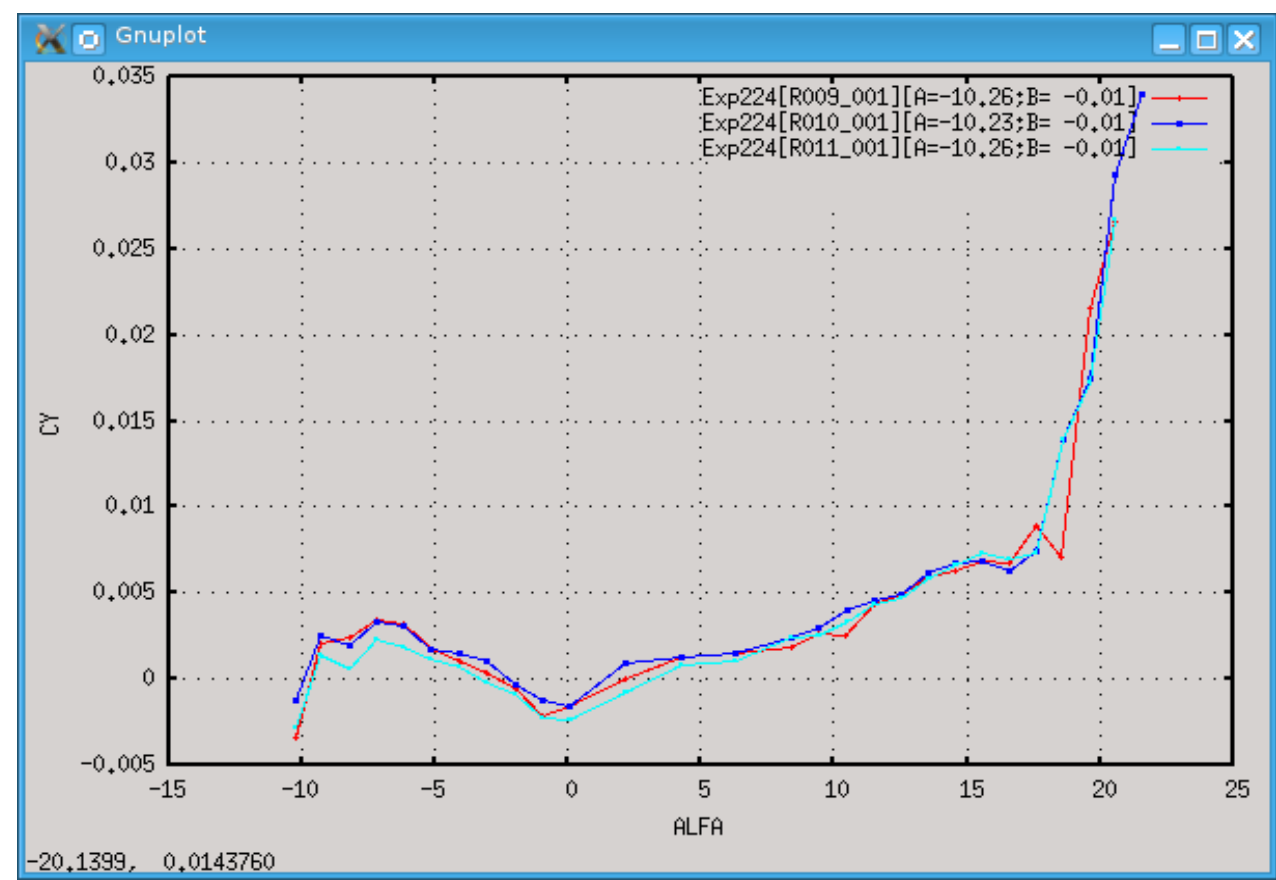

Gambar 4.10. Koefisien $C_{Y}$ baseline clean.

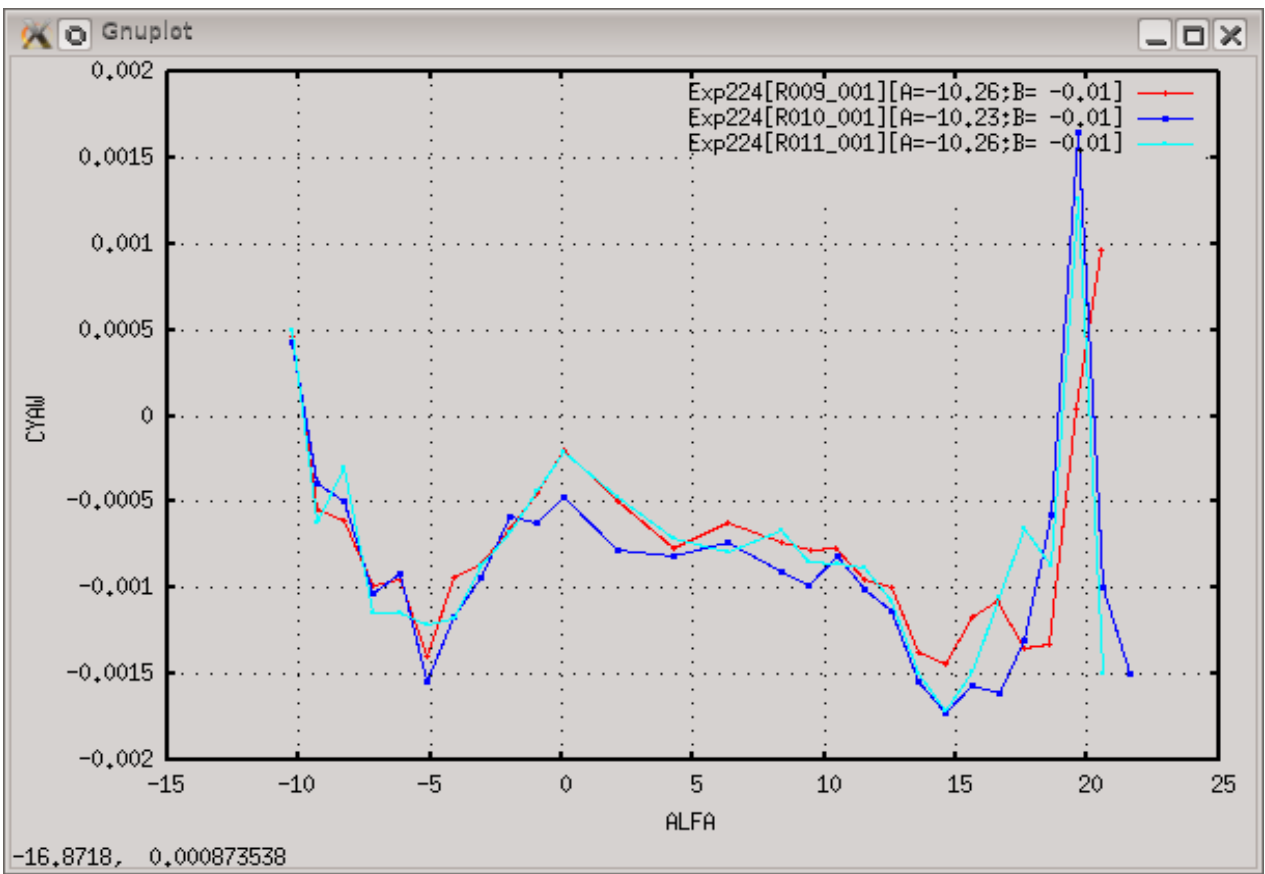

Gambar.4.11. Koefisien $C_{\text {Yaw }}$ baseline clean. 


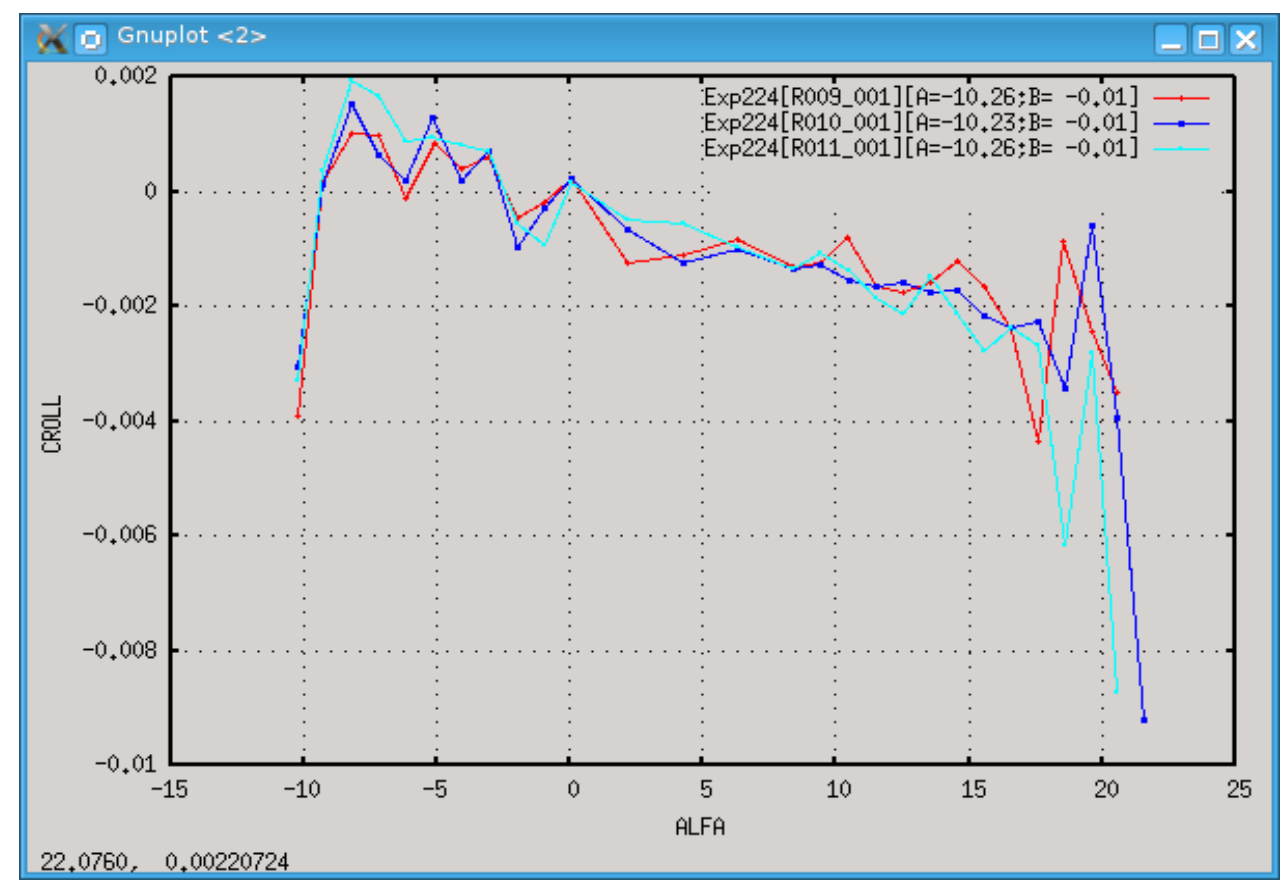

Gambar.4.12. Koefisien $C_{\text {Roll }}$ baseline clean.

Sedangkan test keberulangan jauh dilakukan pada Run 78, Run 80 dan Run 81 untuk konfigurasi W3BNGVHFROYaK pada eksperimen 224 model jenis pesawat penumpang sipil. Hasilnya ditunjukkan pada Tabel 4.2 dan dapat di lihat pada Gambar 4.13 sampai dengan Gambar 4.18. Analisis keberulangan dan pengamatan visual dari hasil pengukuran dan kemudian dilakukan perhitungan secara manual data menunjukkan pengetesan berulang dengan sangat baik, namun jika terjadi beberapa kemungkinan nilai kurva menjauh atau tidak berhimpit sehingga untuk memastikan fenomena yang terjadi di daerah tersebut, dapat dilakukan beberapa langkah; memperhatikan gerak model saat diukur pada posisi tersebut, melihat batas minimum bacaan balance untuk drag force, mengukur kembali dengan sampling rate yang berbeda, atau melakukan visualisasi aliran.

Tabel.4.2. Hasil tes keberulangan jauh.

\begin{tabular}{lllllll}
\hline & \multicolumn{1}{c}{ CL } & \multicolumn{1}{c}{ CD } & \multicolumn{1}{c}{ CM25 } & CYAW & CROLL & CY \\
\hline \hline Deviasi rata-rata & 0.00387 & 0.00084 & 0.00412 & 0.00014 & 0.00045 & 0.00043 \\
Akurasi pengukuran & 0.02256 & 0.00443 & 0.01462 & 0.00085 & 0.00077 & 0.00220 \\
Kriteria & Repeat & Repeat & Repeat & Repeat & Repeat & Repeat \\
\hline
\end{tabular}




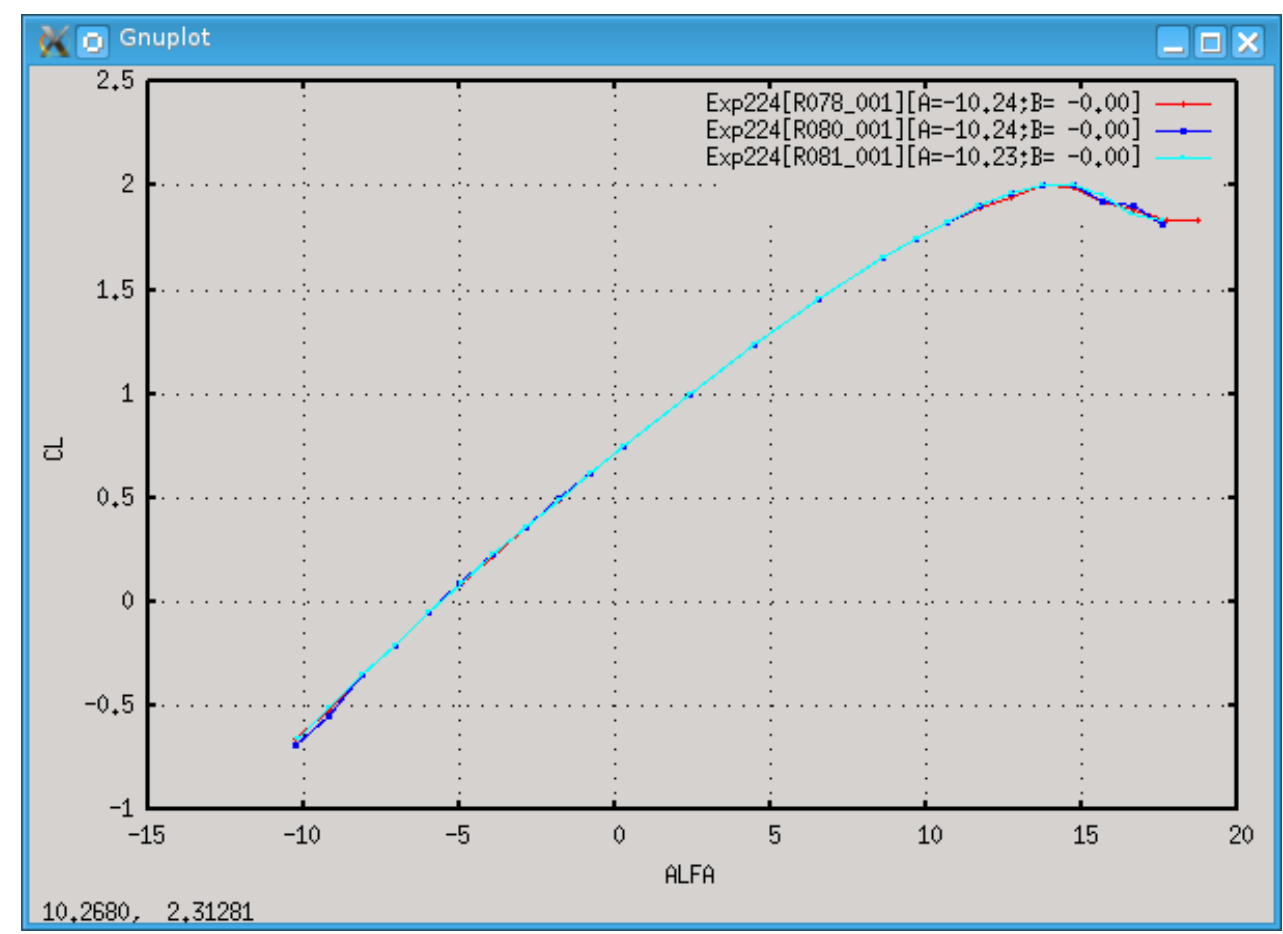

Gambar.4.13. Koefisien $C_{L}$ baseline clean.

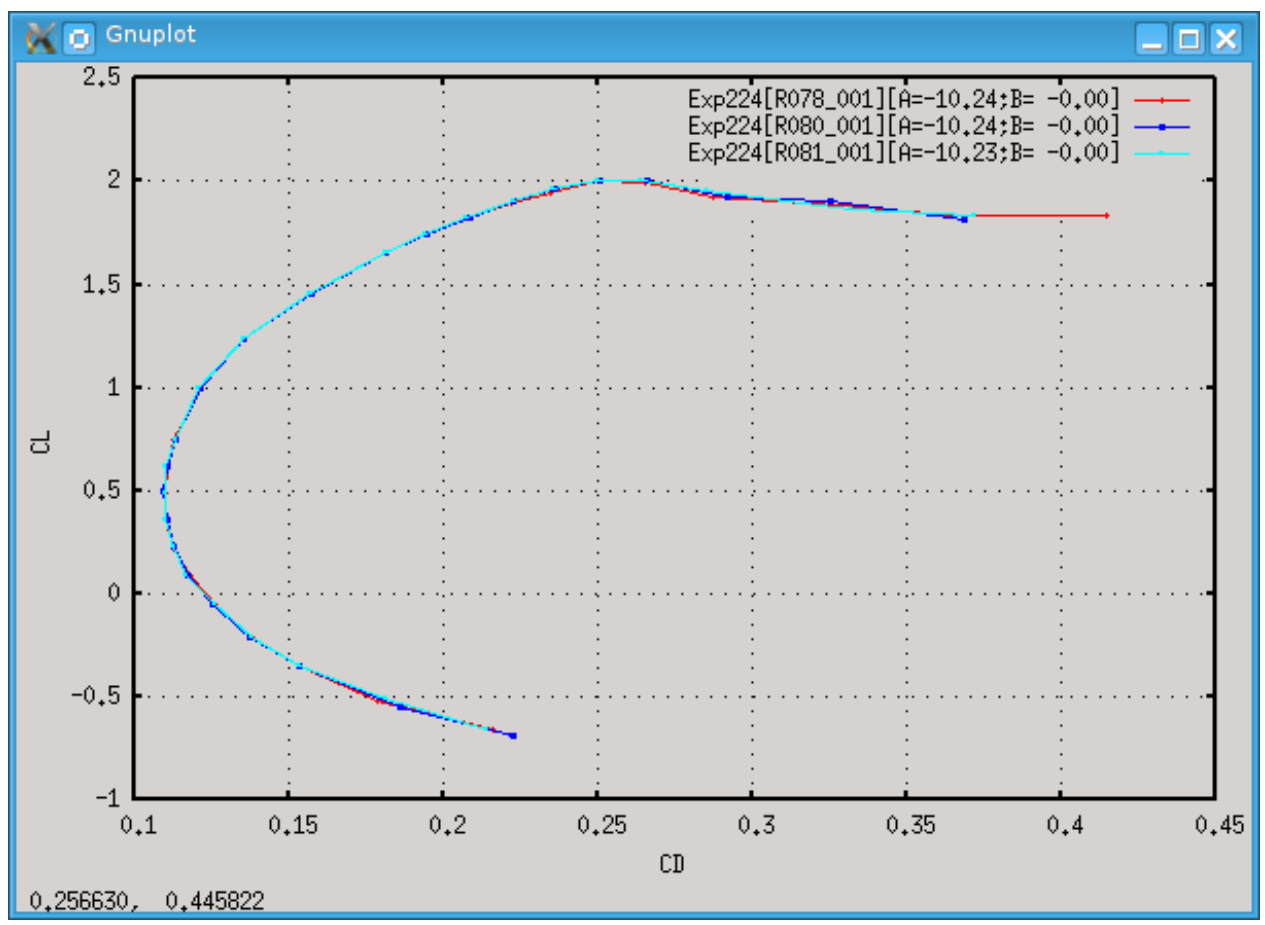

Gambar.4.14. Koefisien $C_{D}$ baseline clean. 


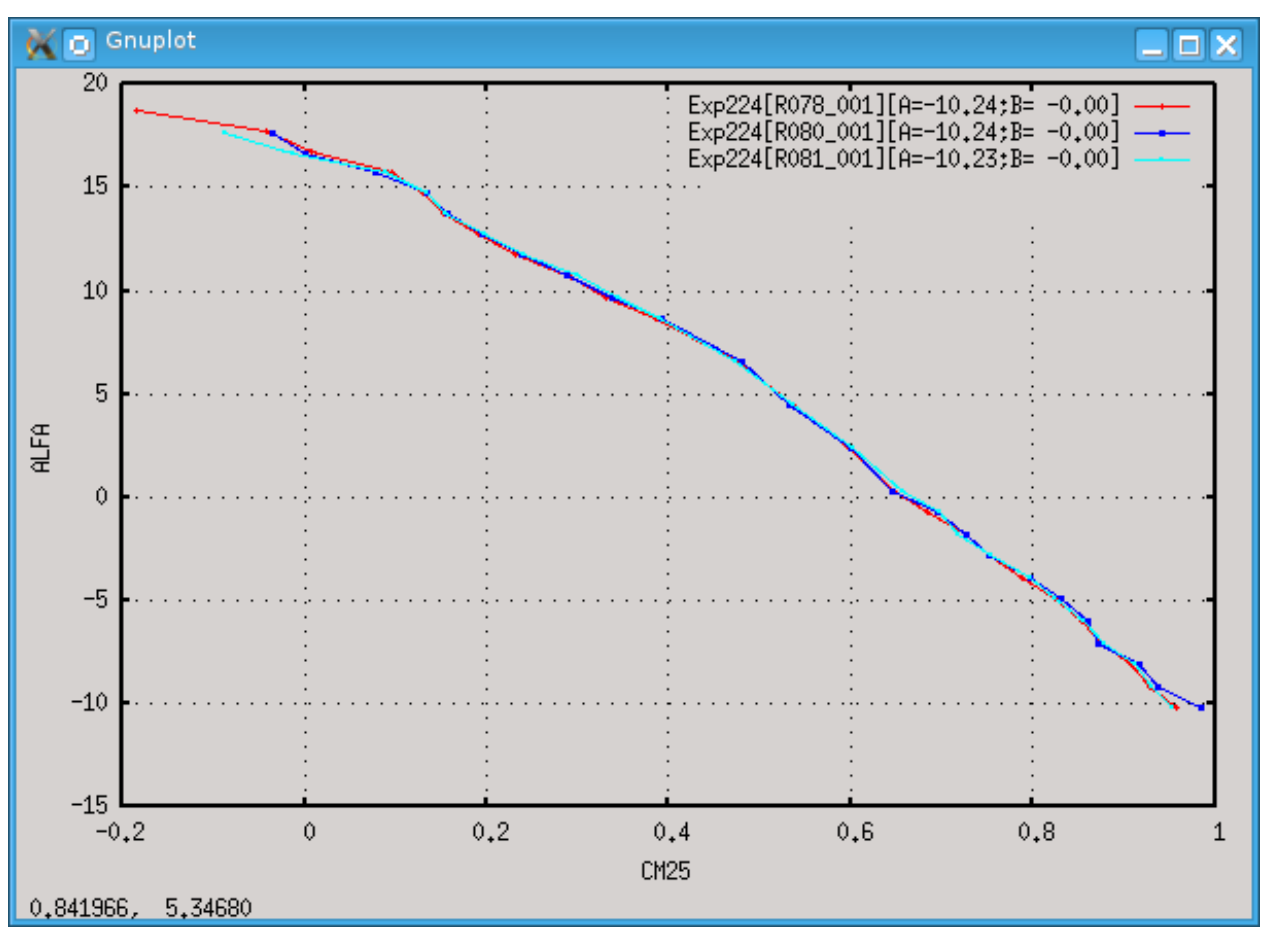

Gambar.4.15. Koefisien $C_{M .25}$ baseline clean.

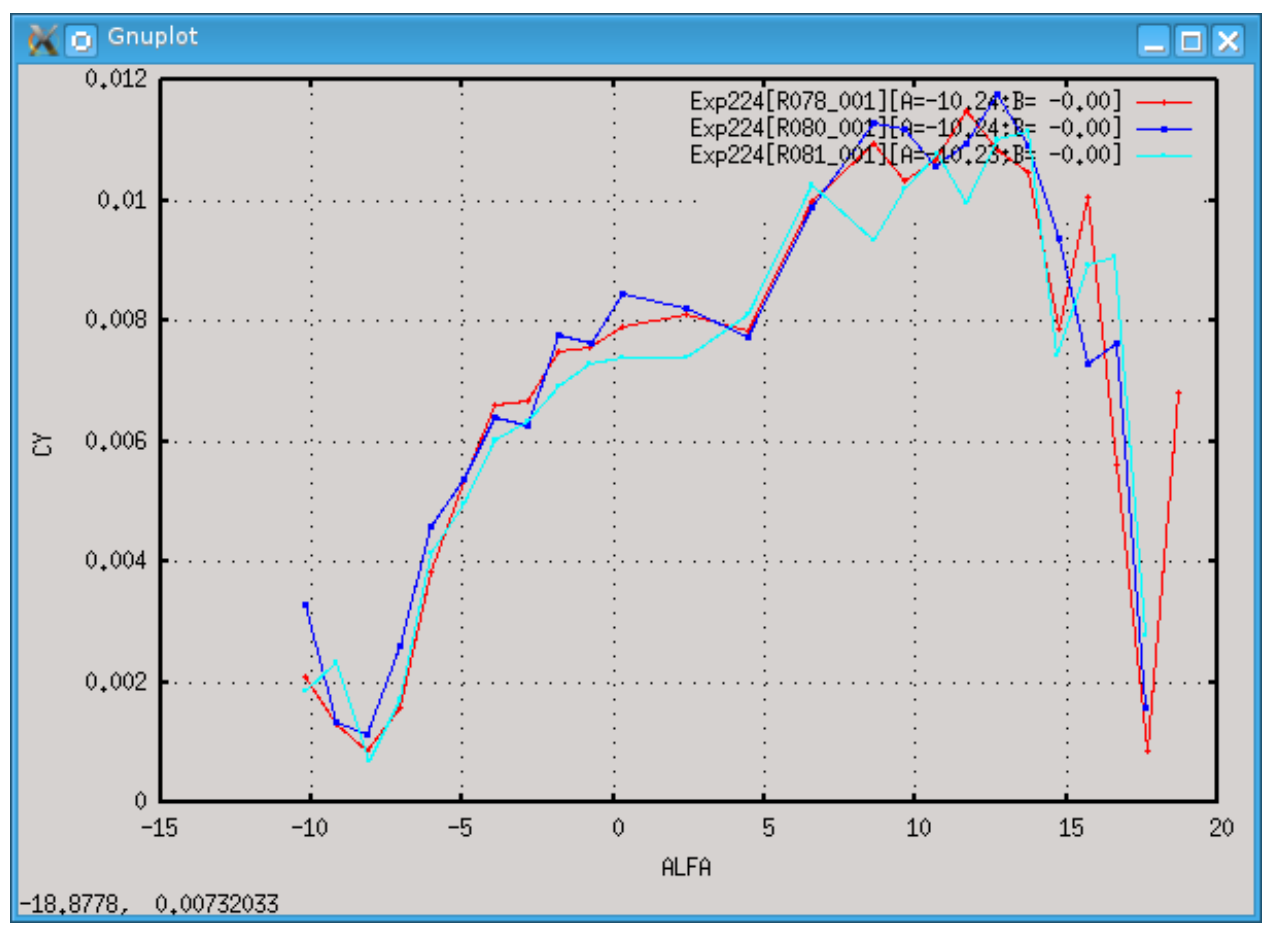

Gambar.4.16. Koefisien $C_{Y}$ baseline clean. 


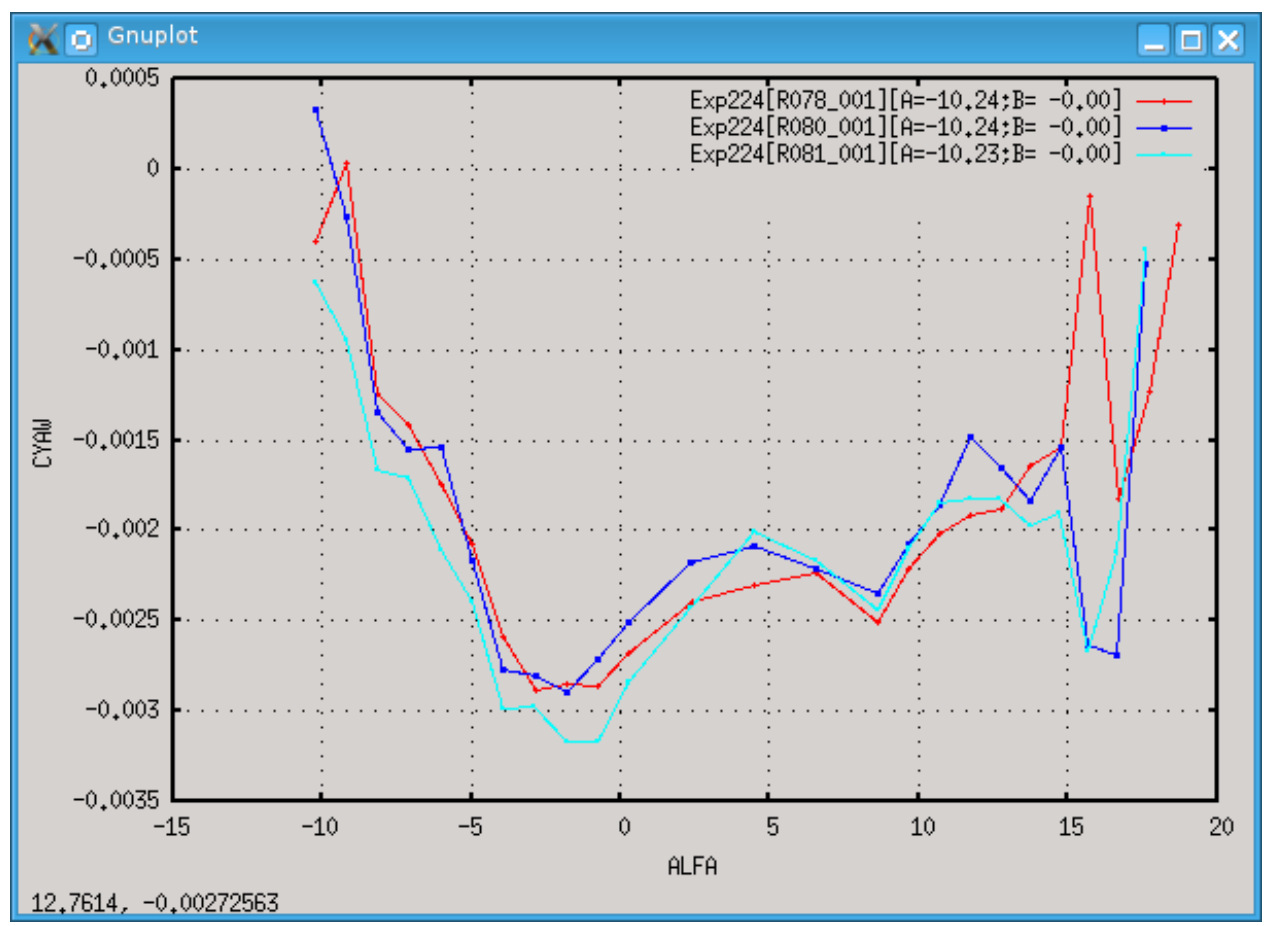

Gambar.4.17. Koefisien $C_{\text {Yaw }}$ baseline clean.

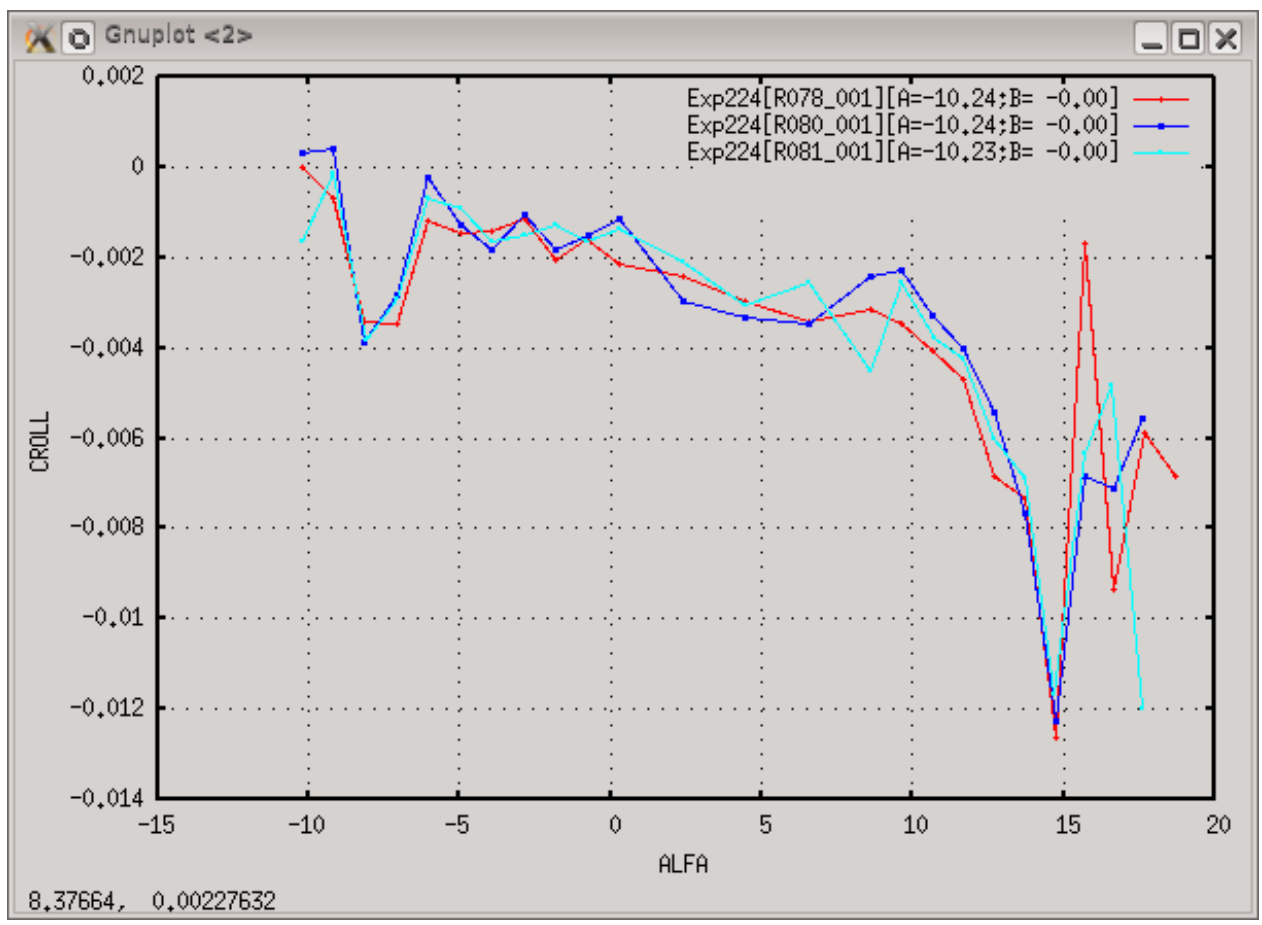

Gambar.4.18. Koefisien $C_{\text {Roll }}$ baseline clean.

\section{KESIMPULAN}

Metoda analisis aerodinamika pada pengujian pesawat jenis penumpang sipil (AirLiner) di terowongan angin merupakan metoda yang efektif untuk memprediksi beban aerodinamik dan setabilitas pesawat terbang yang akan di rancang atau di buat, BBTA3 suatu unit di BPPT yang telah melakukan pengujian model pesawat dengan jenis penumpang sipil (AirLiner) di ILST (Indonesia Low Sped Wind Tunnel) yang bertujuan untuk mendapatkan karakteristik aerodinamika sebelum pesawat di buat.

Untuk memastikan data hasil pengukuran dinyatakan valid maka dilakukan pengukuran yang berulang sehingga terlihat konsisntensi data yang di dapat, dengan demikian bahwa data hasil pengukuran tersebut bisa di gunakan sebagai data untuk mewakili keseluruhan pengukuran dalam pengujian karena dengan tingkat akurasi kekonsistenan data hasil pengukuran tersebut. 
Hasil perbandingan pada konfigurasi clean W3BNGVH pada Eksperimen 224 dan 162 untuk mengetahui kualitas data yang di hasilkan yang menyangkut konsistensi data pengukuran, namun yang terjadi terlihat jauh berbeda hasil yang di dapat dari kedua data yang di hasilkan bisa di katakana dengan terjadinya hal tersebut ada kemungkinan yang terjadi yaitu kualitas model uji yang sudah mengalami perubahan atau dikarenakan dari pergeseran bacaan instrumentasi terowongan angin.

Dengan mendefinisikan $E_{i}$ komponen external balance yaitu Akurasi data hasil dari pengukuran dapat terlihat pada kolom tabel 4.1 hasil tes keberulangan dekat dan tabel 4.2 hasil tes keberulangan jauh yang menyebutkan tingkat akurasi yang cukup baik dengan tingkat error yang sangat sedikit.

\section{Daftar Pustaka}

[1] Abot, Theory of Wing Section, Dover Publication Inc., USA, 1960

[2] de Vries, O., "Equations for the Data Processing ILST", NLR TR 87122L, NLR,Amsterdam, 1987.

[3] John J.Bertin/Michael L.Smith., Aerodynamic for Engineering, Prentice-Hall, Inc.,Englewood Cliffs, New Jersey 076323, 1979.

[4] Nelson, R.C.,"Flight Stability and Automatic Control", McGraw-Hill, Second Ed., 1998.

[5] Roskam, J, "Airplane Flight Dynamics And Automatic Flight Controls", The University of Kansas, 1979.

[6] Widjiatmoko, G., IZ. Pane dan R. Widodo," Laporan Hasil ILST External Balance Calibration : Oktober 1997”, LAGG.TR.,980010.R, LAGG, 1997. 